\title{
NOVEL USES OF THE CHARTER FOLLOWING DORÉ AND LOYOLA
}

\author{
EDWARD J. COTTRILL
}

\begin{abstract}
Doré and Loyola affirmed that administrative decision-makers have a duty to balance statutory aims and values protected by the Charter. In several cases, decision-makers have weighed Charter protections and values on both sides of a contested issue. Sometimes this is a matter of a genuine conflict between different Charter restraints on the state. In other situations, Charter values or even Charter rights have been found to weigh on the side of state action, providing support and justification for an otherwise Charter-infringing state act. Such cases challenge an orthodox understanding of the Charter's nature and role. In this article, the author describes the orthodox view of the Charter within a broadly classical liberal model; that is, as being a restraint on the state, as affecting government rather than private conduct, and as being a source offew free-standing positive entitlements. The author then describes the pre-Doré exceptions to these basic precepts and contrasts the uses made of the Charter by administrative decision-makers via the balancing prescribed in Dore and Loyola, noting where the outcome or analysis has challenged an orthodox conception of our Charter. The article then situates these developments within contemporary discussions of the relevance of orthodox liberal constitutionalism in Canada.
\end{abstract}

\section{TABLE OF CONTENTS}

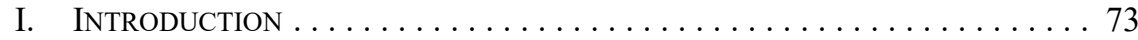

II. ORTHODOX CONSTITUTIONALISM $\ldots \ldots \ldots \ldots \ldots \ldots \ldots \ldots \ldots \ldots$

A. The Charter is a Restraint on State Action $\ldots \ldots \ldots \ldots \ldots 8$

B. The Charter Does Not Apply to Private Conduct $\ldots \ldots \ldots . .82$

C. THE CHARTER's (HistORicAlly) LiMited Positive Rights . . . . . 84

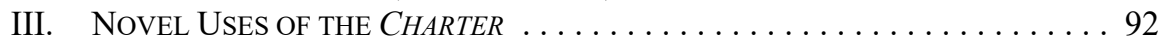

A. Deploying the Charter in Support of State Action . . . . . . . 95

B. ApPlying the Charter to Private Conduct . . . . . . . . . . 98

C. New Positive Charter Rights . . . . . . . . . . . . . . . . . 102

IV. CONSTITUTIONALISM AS AN

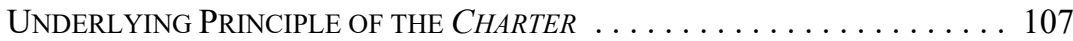

V. CONCLUSION ............................... 114

\section{INTRODUCTION}

The application of the Canadian Charter of Rights and Freedoms ${ }^{1}$ in administrative law has recently generated novel uses that challenge an orthodox conception of the Charter as a classical liberal ${ }^{2}$ constitutional instrument. The Charter has never fit perfectly within the

* CD, BA (Trent), MA (York), LLB (Toronto), LLM candidate (Osgoode). The author thanks Rory Fowler, Ned Fox, Stephanie Keane, Michael Meredith, Gareth Morley, Patrick Phillips, Prem Rawal, and the editors and anonymous reviewers of the Alberta Law Review for their liberally-improving interventions.

Part I of the Constitution Act, 1982, being Schedule B to the Canada Act 1982 (UK), 1982, c 11 [Charter].

By "classical liberal" I mean a political system or ideology that has the aim of maximizing liberty within the rule of law by restraining the state so as to protect people's fundamental freedoms from abuse by the majority. The Charter protects the values most associated with the diverse political traditions of liberalism, that is, freedom of conscience, freedom of expression, security of the person, freedom of movement, and juridical equality. See George H Smith, The System of Liberty: Themes in the History of Classical Liberalism (New York: Cambridge University Press, 2013), especially ch 3. 
framework of classical liberal constitutionalism. The Charter's positive language rights, ${ }^{3}$ the notwithstanding clause, ${ }^{4}$ and arguably the provisions of section $15(2)^{5}$ and the limitations and balancing built into the guarantees of rights and freedoms in section $1,{ }^{6}$ make the Charter something other than an archetypal and unadorned classical liberal instrument. Nonetheless, an orthodox understanding of the Charter's constitutional function has informed the way it has been used. This orthodox view of the Charter has been endorsed by the courts and described by academics. The legislative history and statements by those who drafted and enacted the Charter demonstrate that the Charter's framers shared this view. This understanding places the Charter within a classical liberal tradition in at least three key respects. These are, firstly, that the Charter's essential purpose is to restrain the state. It is a check on the use of power that protects individuals' rights when a well-intentioned democratic majority acts. Its function is not to leverage state power or facilitate state action. The Charter does not weigh on the side of the power of the state. Rather, it subjects state action to the rule of law in order to protect basic freedoms. Secondly, and as a consequence of the conception of the Charter and the constitution generally as controlling the state rather than the populace, the Charter does not directly affect private relations. Positive acts of government, that is laws passed by the legislative branch and things done by the executive branch of government, are subject to the Charter; the actions of voluntary associations, companies, and individuals are not. Thirdly, the Charter mainly protects negative rights, or negative liberty, in the sense described by Isaiah Berlin. ${ }^{7}$ That is to say, the rights in the Charter are legal tools for protecting freedoms. They are shields from coercion. With some narrow exceptions (that I will discuss below), they have not been the source of positive entitlements.

In summary, for the most part, the Charter restrains the state, it restrains only the state, and it only restrains the state. This orthodox conception of the Charter is not a settled normative principle of Canadian constitutionalism, however. Administrative decision-makers are not necessarily constrained by it in their application of the Charter. Administrative law has evolved to direct those who exercise a statutory discretion to consider not only when the

Charter, supra note 1, ss 16-23.

Ibid, s 33.

Ibid, s 15(2).

Ibid, s 1 .

Isaiah Berlin, "Two Concepts of Liberty" in Isaiah Berlin, Four Essays on Liberty (Oxford: Oxford University Press, 1969) 118. Negative liberty involves protection from interference with freedoms, whereas positive liberty consists in self-governance and the ability to act, including acting collectively. Berlin states that he chose the term "following much precedent" (ibid at 121). The distinction originated with Bentham. In a letter to John Lind, Bentham claimed authorship (which Lind then duly acknowledged): "I communicated to you a kind of discovery I thought I had made, that the idea of Liberty, imported nothing in it that was positive: that it was merely a negative one: and that accordingly I defined it "the absence of restraint." (Letter from Jeremy Bentham to John Lind (27 March - 1 April 1776) in Timothy LS Sprigge, ed, Correspondence of Jeremy Bentham, vol I (London: UCL Press, 2017) 309 at 310). The concept was popularized by Thomas Hill Green in "Liberal Legislation and Freedom of Contract," (Oxford: Slatter and Rose, 1881). Negative and positive freedom was discussed in Guido De Ruggiero, The History of European Liberalism, translated by RG Collingwood (Boston: Beacon Press, 1959) at 350-57. The terminology is described in Friedrich A Hayek's "Liberty and Liberties," ch 1 of The Constitution of Liberty (Chicago: University of Chicago Press, 1960) and in George Crowder, "Negative and Positive Liberty" (1988) 40:2 Political Science 57. Berlin also cites Benjamin Constant as a source, whose "The Liberty of the Ancients Compared with That of the Moderns," reprinted and translated in Biancamaria Fontana, ed, Benjamin Constant: Political Writings (Cambridge: Cambridge University Press, 1988) 309, contrasts Greek and American models of government, via a consideration of the tendency of Rousseau and others to mistake "the authority of the social body for liberty" (ibid at 318 ). 
Charter might preclude a certain decision or action, but also when Charter values (and even Charter rights) might weigh in favour of action by the state.

The Supreme Court of Canada's 2012 decision in Doré v. Barreau du Québec ${ }^{8}$ requires decision-makers exercising a statutory authority to consider Charter values when they act. Doré involved a lawyer disciplined by his law society for sending an intemperate letter to a judge.

The Charter value engaged was protection of(Doré's) freedom of expression (though the disciplinary decision was allowed to stand). In 2015 the Supreme Court confirmed the duty of administrative decision-makers to balance Charter values in its decision in Loyola High School v. Quebec (Attorney General). ${ }^{9}$ There, the issue was whether the Quebec Minister of Education had acted properly in refusing to give religious accommodation to a private Catholic school regarding a component of the required curriculum involving religion, the Program on Ethics and Religious Culture (ERC). The Charter value involved in that case was freedom of religion as it applied to the private school, but it is significant that in discussing the values involved, Justice Abella ${ }^{10}$ described the objectives underlying the ERC program as "promoting respect for others and openness to diversity." 11 A defensible decision, the majority held, "must accord with the fundamental values protected by the Charter," 12 which entails that religious freedom must be understood in the context of a society with an interest in "protecting dignity and diversity, promoting equality, and ensuring the vitality of a common belief in human rights." $"$ The majority held that the Minister's decision was unreasonable and that an accommodation in the way Loyola taught the ERC program was called for. The majority stated, however, in its balancing of Charter rights and values, that the aims of the ERC program aligned with the Charter's fundamental values, ${ }^{14}$ which support private religious schools being required to teach religion in a manner that promotes equality and diversity.

In other cases after Doré, this weighing of Charter rights and values on the side of the goals of the state has become more explicit. In Ismail v. British Columbia (Human Rights Tribunal) ${ }^{15}$ for example, the Supreme Court of British Columbia held that the objective of provincial hate speech legislation was "grounded in the Charter value of equality," "which "must be balanced with the severity of the interference with the Charter value of freedom of expression." 17

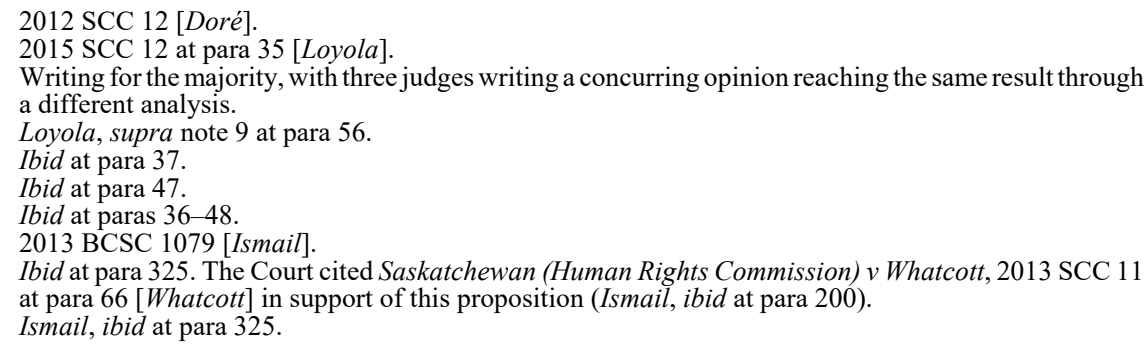


The weighing of Charter rights and values in the context of administrative decisionmaking is a process in which the orthodox model of the function of the Charter has been significantly modified, to the extent that the Charter can provide a foundation for state action, become relevant to private conduct, and support positive entitlements. The Doré/Loyola $(D / L)$ balancing approach to administrative decision-making has seen the Charter enlisted on the side of anti-discrimination and hate-speech laws enforceable within the private sphere ${ }^{18}$ the retention of union employees wishing to decertify during a labour dispute, ${ }^{19}$ and the retention of union employees within a bargaining group. ${ }^{20}$ The $D / L$ framework has been employed in analyzing the extent to which state agencies might properly withhold benefits from private voluntary associations that discriminate on religious grounds. ${ }^{21}$ It has been invoked to review a decision to suspend passport services for providing false information on an application. ${ }^{22}$ It has been used to appeal a decision to suspend payment of income assistance benefits because of the recipient's refusal to apply for Canada Pension Plan benefits, ${ }^{23}$ to claim status under the Indian Act in the absence of proof of paternity, ${ }^{24}$ to seek religious accommodation in the public school system, ${ }^{25}$ and to appeal the denial of a Canada Pension Plan disability pension. ${ }^{26}$ The framework has been used to obtain an order of mandamus to require Health Canada to disclose clinical trial reports to an academic, ${ }^{27}$ and to set aside a decision to refer a report of serious criminality to an immigration admissibility hearing. ${ }^{28}$ It is also being used to challenge the decision of the Ontario Minister of Education to change the sex-education curriculum. ${ }^{29}$ The nature and variety of applications of the Charter will no doubt multiply as Doré and Loyola are applied by various administrative tribunals and other decision-makers, in innumerable different contexts. Advocacy within administrative law currently provides considerable opportunity for innovation as to how the Charter should be understood and applied by decision-makers, and how its function might evolve.

Taylor-Baptiste v OPSEU (No 2), 2013 HRTO 180, aff'd 2014 ONSC 2169 [Taylor-Baptiste Tribunal] (Charter section 15 rights argued at paras 6, 31,44 of the Human Rights Tribunal decision). The Ontario Court of Appeal found that Charter sections 2(b) and 2(d) were properly given greater weight in this case: Taylor-Baptiste v Ontario Public Service Employees Union, 2015 ONCA 495, leave to appeal to SCC refused, 36647 (9 June 2016) [Taylor-Baptiste CA]; Ismail, supra note 15 at paras 185, 200, 211, 325,340 .

19 Certain Employees of Brandt Tractor Ltd v International Union of Operating Engineers, Local 115, 2012 CanLII 53287 (BC Labour Relations Board) [Brandt Tractor], followed in Certain Employees of Canadian Corps of Commissionaires v Canadian Corps of Commissionaires, 2013 CanLII 10980 (BC Labour Relations Board); Certain Employees v Unifor, Local 114, 2015 CanLII 58399 (BC Labour Relations Board).

$20 \quad$ Wsáneć School Board v British Columbia, 2017 FCA 210 [Wsáneć School Board].

21 Trinity Western University v Law Society of Upper Canada, 2016 ONCA 518 [TW v LSUC CA], aff'd 2018 SCC 33 [TW v LSUC SCC]; Trinity Western University v Law Society of British Columbia, 2016 BCCA 423 [TW $v$ LSBC CA], rev'd 2018 SCC 32 [TW $v$ LSBC SCC].

Thelwell $v$ Canada $(A G), 2017$ FC 872 [Thelwell].

Stadler v Director, St Boniface, 2017 MBCA 108 [Stadler].

Gehl v Canada (Attorney General), 2017 ONCA 319 at paras 38-53 [Gehl].

ET v Hamilton-Wentworth District School Board, 2017 ONCA 893 [ET v Hamilton-Wentworth].

MD v Minister of Employment and Social Development (25 October 2017), AD-16-1237 (Social Security Tribunal), online: <https://www1.canada.ca/en/sst/ad/pdf/sst-2017-sstadis-553.pdf>.

Doshi v Canada (Attorney General), 2018 FC 710 at paras 83-87.

Abdi v Canada (Public Safety and Emergency Preparedness), 2018 FC 733.

LM (Litigation guardian of) v Ontario (Minister of Education) (23 August 2018), Toronto 526/18 (Sup Ct J (Div Ct)), online: <ccla.org/cclanewsite/wp-content/uploads/2018/08/Notice-of-Application-forJudicial-Review-issued-Aug-23-2018.pdf $>$. 
In order to show that the use and understanding of the Charter may be changing, I direct some attention by way of groundwork in Part II, below, to establishing the Charter's orthodox constitutionalism (with the necessary caveats and limitations). The proposition that the Charter is essentially a classical liberal constitutional instrument has been the focus of considerable critical attention by some (see Part IV, below). For others, it is trite law. Readers in the latter category may prefer to proceed directly to Part III of this article.

Part III is aimed at explicating the changes in the Charter's use that are arising through the application of the $D / L$ framework. The $D / L$ framework is not solely responsible for the shift away from orthodox constitutionalism. Some anomalous cases provide fulcra for the $D / L$ lever. Through the legal latitude inherent in "Charter values" and the standard of reasonableness in the exercise of discretion, the $D / L$ framework sometimes amplifies novelties in judicial interpretation. So, for example, the proposition in Health Services and Support - Facilities Subsector Bargaining Assn. v. British Columbia ${ }^{30}$ that section 2(d) of the Charter includes a right to a process of collective bargaining becomes, in Brandt Tractor ${ }^{31}$ Charter support for a majoritarian principle in the Canada Labour Code, ${ }^{32}$ and the rule that a person cannot - because of his or her right to freedom of association - leave a union during a labour dispute. This is a paradoxical outcome, and a novel one. Labour tribunals have recognized majoritarian principles as instantiated in legislation for some time ${ }^{33}$ but it is only since $B C$ Health Services that the majoritarian principle has taken root within section 2(d) of the Charter. In Part III, I attempt to show that this outcome in administrative law has resulted from the conjunction of the $D / L$ lever with the "derivative rights" labour cases that constitutionalize the Wagner Act model of labour relations. ${ }^{34}$ Similarly, in Ismail, ${ }^{35}$ Charter equality rights were invoked via provincial human rights legislation in the exercise of administrative discretion involving a comedy club emcee's treatment of a patron. What the Charter has to do with an interaction between two people at a private business is not manifestly obvious, and the answer to that question is not rendered less obscure by the light of orthodox constitutional theory. In Whatcott, the Supreme Court held that not only Charter values, but Charter equality rights themselves, support provincial hate speech legislation ${ }^{36}$ (see discussion in Part III.A, below). In doing so, the Supreme Court endorsed a view of positive Charter equality entitlements that administrative bodies such as provincial and federal human rights commissions have often articulated (see Part III.C, below). In Ismail, again, $D / L$ balancing acts as a lever, this time with the fulcrum of the conception of Charter equality rights as stated in Whatcott. A proposition establishing the constitutionality of a law (that Charter equality rights support anti-discrimination legislation) is thereby used to affect the exercise of discretion in an actual case, placing the weight of the

2007 SCC 27 [BC Health Services].

Supra note 19, citing Charter, supra note 1, s 2(d).

RSC 1985, c L-2.

See e.g. Restaurant, Cafeteria and Tavern Employees Union (Hotel and Restaurant Employees and Bartenders International Union, Local 254) v Domco Foodservices Limited, 1980 CanLII 919 at para 6 (Ont Labour Relations Board); Nova Scotia (Labour Relations Board) v Digby Municipal School Board, 1982 CanLII 2889 at para 56 (NSCA), citing United Steelworkers of America v Radio Shack, [1980] 1 Can LRBR 99 at 117-19 (Ont Labour Relations Board); United Brotherhood of Carpenters and Joiners of America, Local $1998 v$ United Brotherhood of Carpenters and Joiners of America, Local 2397, 2000 CanLII 27257 at paras 41, 54, 80 (BC Labour Relations Board).

National Labor Relations Act, 29 USC $\$ § 151-69$ (1935) [Wagner Act].

Supra note 15.

Whatcott, supra note 16 at paras 66-68, 112, 114, 145, 154, 161. 
Charter on the balance in favour of the state to restrain the conduct of an individual. In the result, the Charter takes on a new role in private relations.

Finally, in Part IV, I consider whether orthodox constitutionalism is sufficiently entrenched in Canada as a normative standard or formal understanding of the Charter's structure to provide limits to innovation via the $D / L$ framework.

\section{ORTHODOX CONSTITUTIONALISM}

The Charter was drafted during a time of a significant resurgence of classical liberalism. The English philosopher John Gray has described the disintegration of the post-war Keynesian model in the 1970 s, which coincided with an "extraordinary revival of liberal ideas in political philosophy." 37 Gray points to the publication of John Rawls's $A$ Theory of Justice (1971), Robert Nozick's Anarchy, State, and Utopia (1974), Friedrich Hayek's The Constitution of Liberty (published in 1960, but not read widely until the 1970s), the awarding of the Nobel Prize in economics to Hayek in 1974 and to Milton Friedman in 1976, and James Buchanan's Freedom in Constitutional Contract (1977). ${ }^{38}$ Ronald Dworkin's Taking Rights Seriously ${ }^{39}$ was also published in 1977. Gray describes this as a time of "inquiry into the conditions of constitutional government fully as profound as any produced by the eighteenth-century political economists." 40 The basic premises of universalism and the primacy of individual freedom had academic support in Canada. ${ }^{41}$ William Conklin's In Defence of Fundamental Rights, published in 1979, articulated a theory of legitimacy based on the extent to which a legal system protects an "inner sphere of life" from interference by the state. ${ }^{42}$ Thomas Berger advocated the entrenchment of fundamental freedoms in Fragile

37 John Gray, Liberalism: Concepts in Social Thought, 2nd ed (Minneapolis: University of Minnesota Press, 1995) at 39.

38 Ibid at 36-41, citing John Rawls, A Theory of Justice (Cambridge, Mass: Harvard University Press, 1971); Robert Nozick, Anarchy, State, and Utopia (New York: Basic Books, 1974); FA Hayek, The Constitution of Liberty (Chicago: University of Chicago Press, 1960); Royal Swedish Academy of Sciences, News Release, "Economics Prize for Works in Economics Theory and Inter-disciplinary Research" (9 October 1974), online: <https://www.nobelprize.org/nobel_prizes/economic-sciences/ laureates/1974/press.html>; Royal Swedish Academy of Sciences, News Release, “This Year's Economics Prize to an American" (14 October 1976), online: $<$ https://www.nobelprize.org/nobel prizes/ economic-sciences/laureates/1976/press.html>; James M Buchanan, Freedom in Constitutional Contract: Perspectives of a Political Economist, 1 st ed (College Station: Texas A \& M University Press, 1977).

39 Ronald Dworkin, Taking Rights Seriously (Cambridge, Mass: Harvard University Press, 1977). See especially his characterization of constitutional rights as restraints on the state that take priority over a utilitarian calculation of social benefits (ibid, $\mathrm{ch} 7$ ). For the influence on the development of the Charter (in particular, its exclusion of property rights) of Rawls and Dworkin, see Dwight Newman \& Lorelle Binnion "The Exclusion of Property Rights from the Charter: Correcting the Historical Record" (2015) 52:3 Alta L Rev 543 at 546-50.

$40 \quad$ Gray, supra note 37 at 40.

41 See e.g. TC Pocklington, "Democracy" in TC Pocklington, ed, Liberal Democracy in Canada and the United States: An Introduction to Politics and Government (Toronto: Holt, Rinehart and Winston of Canada, 1985) 1 at 18. There were also some prominent Canadian academics who preferred a communitarian conception of government powers (see e.g. Charles Taylor, "The Agony of Economic Man" in Laurier LaPierre et al, eds, Essays on the Left (Toronto: McLelland and Stewart, 1971) 221; CB Macpherson, The Life and Times of Liberal Democracy (Oxford: Oxford University Press, 1977)).

42 William E Conklin, In Defence of Fundamental Rights (Alphen aan den Rijn, Netherlands: Sijthoff \& Noordhoff, 1979) at 201-205. 
Freedoms (1981). ${ }^{43}$ The Charter was enacted with broad support ${ }^{44}$ for Pierre Trudeau's universalist liberal constitutionalism. ${ }^{45}$

Numerous factors other than a national concern for protection from arbitrary use of power or from the unfettered will of the majority have been cited to explain the impetus for the Charter, such as the desire to create greater national identity and unity, and the related need to extend language rights. ${ }^{46}$ Also cited, however, are the demands by civil libertarians for protections from the state in the decades following the Second World War, with increasing knowledge of state atrocities including genocide by the Nazis and mass killings by other totalitarian regimes. ${ }^{47}$ Domestically, the internment of Japanese Canadians, the treatment of Jehovah's Witnesses under Duplessis, the use of the War Measures Act in 1970, and the failure of the Diefenbaker Bill of Rights to provide robust protections of basic liberties created a civic demand for the Charter. ${ }^{48}$ The Charter was entrenched in recognition of the fact that state power can be misused.

The Charter was promoted as "[a] constitutional bill of rights [that] would guarantee the fundamental freedoms of the individual from interference, whether federal or provincial." ${ }^{\circ 9}$ On its introduction, the aim of the Charter was described in a government publication as making it "much more difficult for any government or legislature ... to tamper with basic

Thomas R Berger, Fragile Freedoms: Human Rights and Dissent in Canada (Toronto: Clarke, Irwin, \& Company, 1981).

Two national opinion polls conducted in the summer of 1981 showed 72 percent and 82 percent support for a charter of rights that would "provide individual Canadians with protection against unfair treatment by any level of government in Canada" (Michael Mandel, The Charter of Rights and the Legalization of Politics in Canada (Toronto: Thompson Educational Publishing, 1994) at 27). A poll in September 1981 showed 81 percent support for a constitutional guarantee of rights and freedoms "in such a way that no law, federal or provincial, could go against them" (Senate and House of Commons, Minutes of Proceedings and Evidence of the Special Joint Committee of the Senate and House of Commons on the Constitution of Canada, 32nd Parl, 1st Sess, No 34 (8 January 1981) at 152 [Proceedings of SJC] . In his final speech to Parliament before the Charter was adopted, Pierre Trudeau was able to cite three polls between August of 1980 and March of 1981 showing strong support for the Charter, including a Gallup poll result showing 91 percent support for the proposition that the constitution should guarantee basic human rights: House of Commons Debates, 32nd Parl, 1st Sess, Vol 8 (23 March 1981) at 8506-07, Right Hon PE Trudeau, online: <parl.canadiana.ca/view/oop.debates HOC3201 08/292? r=0\&s=1>. See James Bickerton, Stephen Brooks \& Alain-G Gagnon, Freedom, Equality, Community: The Political Philosophy of Six Influential Canadians (Montreal: McGill-Queen's University Press, 2006) at 119ff. See e.g. Peter H Russell, "The Political Purposes of the Canadian Charter of Rights and Freedoms" (1983) 61:1 Can Bar Rev 30; Ian Greene, The Charter of Rights (Toronto: James Lorimer \& Company, 1989) at 37-38; BL Strayer, "In the Beginning...: The Origins of Section 15 of the Charter" (2006) 5:1 JL \& Equality 13.

47 Robert J Sharpe, Katherine E Swinton \& Kent Roach, The Charter of Rights and Freedoms, 2nd ed (Toronto: Irwin Law, 2002) at 12-15. There were a series of revelations through the 1970s of the atrocities and failures of coercive states. For example, Robert Conquest, The Great Terror: Stalin's Purge of the Thirties (London: MacMillan, 1968); Aleksandr I Solzhenitsyn, The Gulag Archipelao 1918-1956: An Experiment in Literary Investigation III-IV, translated by Thomas P Whitney (New York: Harper \& Row, 1975); Edward E Rice, Mao's Way (Berkeley: University of California Press, 1972) (reporting malnutrition and starvation following Mao's "Great Leap," though the scale of the failure and famine was not widely known outside China for another decade); François Ponchaud, Cambodia: Year Zero, translated by Nancy Amphoux (New York: Holt, Rinehart \& Winston, 1978). Russell, supra note 46 at 33; Christopher MacLennan, Toward the Charter: Canadians and the Demand for a National Bill of Rights, 1929-1960 (Montreal: McGill-Queen's University Press, 2003) at 110-25; Peter W Hogg, Constitutional Law of Canada, 5th ed, vol 2 (Toronto: Thomson reuters, 2007) (looseleaf revision 2015), ch 36.1 [Hogg, Constitutional Law]; Marian Botsford Fraser, Sukanya Pillay \& Kent Roach, Acting for Freedom: Fifty Years of Civil Liberties in Canada (Toronto: Second Story Press, 2014) at 25-84. See also Government of Canada, The Constitution and You (Ottawa: Government of Canada, 1982) at 11-12.

49 Pierre Elliott Trudeau, A Canadian Charter of Human Rights (Ottawa: Queen's Printer, 1968) at 11 [emphasis added]. 
human rights and freedoms." ${ }^{50}$ Barry Strayer has written that "it is fair to say that the concept of a constitutional bill of rights was that of a protector of 'negative rights' — that is, a protector of citizens' liberty and freedom of choice from the interference of government." The Supreme Court rightly noted, in the Reference re BC Motor Vehicle Act, that the exercise of discerning a collective intention of the "multiplicity of individuals who played major roles in the negotiating, drafting and adoption of the Charter," through speeches, letters, and publications made at various times for various purposes, amounts to seeking "a fact which is nearly impossible of proof." 52 The group involved in creating the Charter (which arguably includes all involved in discussions of the Charter from the Federal-First Minister's conference in February 1968 until the final resolution in November of 1981) was not politically homogenous. No doubt they had theories of the constitution which varied accordingly. ${ }^{53}$ Nonetheless, there is ample support for the general proposition that the Charter was designed chiefly to protect minority language rights and reduce the state's power to impair freedoms. In an early description of his conception of an entrenched bill of rights, Pierre Trudeau wrote:

\footnotetext{
A Bill of Rights could be incorporated into the constitution, to limit the powers that legal authorities have over human rights in Canada. In addition to protecting traditional political and social rights, such a bill would specifically put the French and English languages on an equal basis before the law. ${ }^{54}$
}

Trudeau was successful in achieving this aim. ${ }^{55}$ The proposed joint resolution of October 1980 presented an instrument which protected language rights and restrained the state. The resolution stated that the Charter would "place those [entrenched] rights beyond the ordinary reach of Parliament or a single provincial legislature."56 The two aims of restraining government and providing positive powers to control private conduct were kept clearly distinct when the Charter was adopted, as is plain from a statement by Senior Counsel from the Department of Justice at the hearings of the Special Joint Committee on the Constitution:

I think the whole of the Charter is addressing itself to the protection of individuals against acts by the state and I would be very worried if we ended up with a Charter that mixed into that the domain of private infringements of liberties and freedoms. I think those are ones to be left to be dealt with by human rights codes. 57

Government of Canada, The Constitution and You, supra note 48 at 12.

Hon Barry L Strayer, "The Constitution Act, 1982: The Foreseen and Unforeseen" (2007) 16:2 Const Forum Const 51 at 54.

[1985] 2 SCR 486 at 508 [Motor Vehicle Reference].

Jeremy Webber has diagnosed competing visions of the constitution which have existed since its conception and which continue to find expression in doctrines of Canadian constitutional law: Jeremy Webber, The Constitution of Canada: A Contextual Analysis (Oxford: Hart Publishing, 2015), especially at 259-66.

Pierre Trudeau, "Quebec and the Constitutional Problem" in Pierre Elliott Trudeau, Federalism and the French Canadians (Toronto: Macmillan of Canada, 1968) 3 at 44-45 [emphasis added].

CfPhilip Resnick, The Masks of Proteus: Canadian Reflections on the State (Montreal: McGill-Queen's University Press, 1990) ("[h]e had in mind ... a written Charter of Rights that would institutionalize minority-language rights and a variety of classically liberal individual rights and freedoms. By and large the Charter that emerged ... was the document that Trudeau himself desired" at 84).

House of Commons and the Senate, "Proposed Resolution for Joint Address to Her Majesty the Queen Respecting the Constitution of Canada, Tabled in the House of Commons and the Senate, October 6 , 1980" in Anne Bayefsky, Canada's Constitution Act 1982 \& Amendments: A Documentary History, vol 2 (Toronto: McGraw-Hill Ryerson, 1989) 743 at 746.

$57 \quad$ Proceedings of SJC, supra note 44, 32nd Parl, 1st Sess, No 48 (29 January 1981) at 28. 
The fact that the "Charter is, at root, a liberal document" $" 58$ has been employed by its critics as the basis of an argument that it favours the status quo, ${ }^{59}$ or is based on outmoded ideas. ${ }^{60}$ Such criticism demonstrates that while there is a near-consensus that the Charter can be described as being at core a classical liberal document, there is less agreement as to whether this conception should retain any normative traction as its function evolves through successive purposive interpretations.

\section{A. The Charter is a Restraint on State ACtion}

The aim of limiting the powers of government was reflected in the instrument eventually adopted after a long process of consultation. At the special Joint Committee, the Minister of Justice made it clear that "this charter does not give us any new powers at the federal Parliament, but curtails the power of the federal Parliament and the provincial Parliament to do certain things." ${ }^{\prime 1}$ In his final speech to Parliament on the Charter in 1981, Trudeau was able to say that "the charter in fact takes away a little of the powers of all the governments." Sections 31 and 32 of the Charter as enacted express the key classically-liberal concepts that a constitutional bill of rights does not extend any legislative powers, and that the Charter applies only to the Parliament and the Government of Canada.

Academics writing on the Charter consistently endorse the orthodox understanding that its aim is to limit government, and not to extend positive entitlements or affect private conduct. For instance, Professor Peter Hogg: "The Charter of Rights, like any other bill of rights, guarantees a set of civil liberties that are regarded as so important that they should receive immunity, or at least special protection, from state action." ${ }^{\prime 63}$ Professors Robert Sharpe, Katherine Swinton, and Kent Roach: "In sum, the Canadian catalogue of rights and freedoms in the Charter looks essentially liberal in nature, in the sense that its language of rights and freedoms seems to define a zone of autonomy for the individual within which the state may not intrude." ${ }^{\prime 4}$ Professor David Beatty: "Rather than empowering individuals and governments to do various things, the rules of constitutional law actually impose limits on how those (politicians and government officials) who are entrusted with the powers of the state can behave." ${ }^{\prime 5}$ Professor Jeremy Webber: "The courts have ... tended to assume that most Charter rights are negative rights.... The courts have been very reluctant, thus far, to suggest there may be anything close to a free-standing right to positive state action. $"{ }^{\circ 6}$

Allan C Hutchinson, Waiting for Coraf: A Critique of Law and Rights (Toronto: University of Toronto Press, 1995) at 131. See also Andrew Petter, The Politics of the Charter: The Illusive Promise of Constitutional Rights (Toronto: University of Toronto Press, 2010) at 81 [Petter, Politics of the Charter]. See e.g. Andrew Petter, "Immaculate Deception: The Charter's Hidden Agenda" (1987) 45:6 Advocate 857 at 857; Petter, Politics of the Charter, ibid especially at 31-35, 77-94, 100-104, 140-41; Hutchinson, ibid, especially at 3-27, 131-36; Mandel, supra note 44 at 340-47, 439ff.

60 Grant Amyot, “The Editor's Column: Liberty and Equality" (1985) 92:1 Queen's Q 231.

${ }_{61} \quad$ Proceedings of SJC, supra note 44, 32nd Parl, 1st Sess, No 49 (30 January 1981) at 28.

62 House of Commons Debates, supra note 44 at 8515.

63 Hogg, Constitutional Law, supra note 48 at 36-3.

$64 \quad$ Sharpe, Swinton \& Roach, supra note 47 at 47.

65 David Beatty, Constitutional Law in Theory and Practice (Toronto: University of Toronto Press, 1995) at 17 . Though Beatty, in this passage, is describing the application of rationality and proportionality as constraints throughout constitutional law, his observation stands a fortiori with regard to the Charter. Webber, supra note 53 at 185-86. Professor Webber does note at 186, citing Vriend v Alberta, 19981 SCR 493 [Vriend] and Dunmore v Ontario (Attorney General), 2001 SCC 94 [Dunmore], that the courts have in some cases responded to the complexities of state involvement in private activity by "building some positive entitlements into certain rights, albeit slowly and tentatively." 
The Canadian courts have repeatedly described the Charter as an instrument that restrains the power of the state. The Supreme Court has held that the function of the Charter is "the unremitting protection of individual rights and liberties," and is "intended to constrain governmental action inconsistent with those rights and freedoms." ${ }^{67}$ The Supreme Court has also held that the Charter "is essentially an instrument for checking the powers of government over the individual," ${ }^{68}$ and "was intended to restrain government action and to protect the individual." ${ }^{69}$ Further, the Supreme Court has held that the Charter preserves a "sphere of liberty" for the individual against the intrusion of state action, ${ }^{70}$ or "an irreducible sphere of personal autonomy wherein individuals may make inherently private choices free from state interference." ${ }^{71}$ While the commitment expressed here may be in tension with some progressive applications of Charter values, it remains fundamental to the orthodox conception of the Charter's role.

\section{B. The Charter Does Not Apply to Private Conduct}

Does the Charter restrain only the state? The courts have generally interpreted section 32 of the Charter to entail that its restraints do not apply to the actions of people and corporations acting in a private capacity. ${ }^{72}$ This general precept comes with a caveat, however. Hogg, in his discussion of the Supreme Court's interpretation of section 32, comments "[i]n deciding that the Charter does not extend to private action, the Supreme

Hunter $v$ Southam Inc, [1984] 2 SCR 145 at 155-56 [Hunter].

McKinney v University of Guelph, [1990] 3 SCR 229 at 261 [McKinney].

RWDSU v Dolphin Delivery Ltd, [1986] 2 SCR 573 at 593 [Dolphin Delivery]. See also Clare Beckton, "Freedom of Expression" in Walter S Tarnopolsky \& Gérald-A Beaudoin, eds, The Canadian Charter of Rights and Freedoms: Commentary (Toronto: Carswell, 1982) 75, cited in Haig v Canada; Haig $v$ Canada (Chief Electoral Officer), [1993] 2 SCR 995 at 1037 [Haig] ("[g]enerally the fundamental freedoms are guaranteed by placing limitations on the state's ability to abrogate or abridge them" at 76). The Charter has multiple functions. It acts as a restraint on the state: $R v$ Morrisey, 2000 SCC 39 at para 92; $R$ v Cornell, 2010 SCC 31 at para 133. Or it functions as a constraint on the state: Canada (Prime Minister) $v$ Khadr, 2010 SCC 3 at para 37; McKinney, ibid at 261, 339-40; $R$ v Malmo-Levine; $R v$ Caine, 2003 SCC 74 at para 204. The Charter "regulate[s] the conduct of our Government in its dealings with individuals by ensuring that it complies with certain basic liberal democratic values" (Schreiber v Canada (Attorney General) (1997), 144 DLR (4th) 711 at 731 (FCA), rev'd [1998] 1 SCR 841); it "controls excesses of government" (Prete v Ontario (1993), 16 OR (3d) 161 at 167 (Ont CA), leave to appeal to SCC refused, 23973 (28 April 1994)), it creates "a boundary between the individual and the state" $(R \vee S(S),[1990] 2$ SCR 254 at 287), and "the right to liberty enshrined in s. 7 of the Charter protects within its ambit the right to an irreducible sphere of personal autonomy wherein individuals may make inherently private choices free from state interference" (Godbout v Longueuil (City), [1997] 3 SCR 844 at para 66 [Godbout]). The rights the Charter guarantees create "an invisible fence over which the state will not be allowed to trespass" ( $R$ v Morgentaler, [1988] 1 SCR 30 at 164 [Morgentaler]).

Irwin Toy Ltd v Quebec (Attorney General), [1989] 1 SCR 927 at 971 [Irwin Toy], citing DFB Tucker, Law, Liberalism and Free Speech (Totowa, NJ: Rowman \& Allanheld, 1985); Morgentaler, ibid at 171, 180, citing Thornburgh $v$ American College of Obstetricians \& Gynecologists, 476 US 747; $R v$ Keegstra, [1990] 3 SCR 697 at 727 [Keegstra].

Godbout, supra note 69 at para 66.

See e.g. Dolphin Delivery, supra note 69 at 604; Tremblay v Daigle, [1989] 2 SCR 530; McKinney, supra note 68; Stoffman v Vancouver General Hospital, [1990] 3 SCR 483 [Stoffman]. This aspect of orthodox constitutionalism is not without controversy: see e.g. Dale Gibson "The Charter of Rights and the Private Sector" (1982-83) 12:2 Man LJ 213; Dianne Pothier "Crossing the Lines in Dolphin Delivery: Some Thoughts on the Parameters of Charter Application" (1987) in Fundamentals of Public Law: Course Materials, vol 5 (Dalhousie School of Law, 1994) at 127; Allan C Hutchinson \& Andrew Petter, "Private Rights/Public Wrongs: The Liberal Lie of the Charter" (1988) 38:3 UTLJ 278; Richard Fader "Reemergence of the Charter Application Debate: Issues for the Supreme Court in Eldridge and Vriend" (1997) 6 Dal J Leg Stud 187; Thomas Michael Joseph Bateman, Charter Rights Application Doctrine and the Clash of Constitutionalisms in Canada (PhD Thesis, University of Alberta, Department of Political Science, 2000), online:<www.collectionscanada.gc.ca/obj/s4/f2/dsk2/ftp02/NQ59929.pdf>. 
Court of Canada has affirmed the normal role of a constitution." ${ }^{73} \mathrm{He}$ also notes, however, that "when it is said that the Charter does not apply to 'private' action, the word 'private' is a term of art, denoting a residual category from which it is necessary to subtract those cases where the existence of a statute or the presence of government does make the Charter applicable." 74 This does not imply that the Charter will follow legislation into every type of private activity that the law touches. An entity such as a university, hospital, or transit authority, for example, may have a statutory mandate, but distinctions are drawn between those parts of their operations that are autonomous and those that are under substantial government control or fulfill a governmental function. ${ }^{75}$ The actions of private entities, therefore, may be restrained by the Charter, but normally only where that action is empowered by legislation.

Some application of an entrenched bill of rights to private conduct, particularly with regard to preventing improper discrimination, was envisaged by Pierre Trudeau as Minister of Justice in 1968, when he considered the possibility of including prohibition of private discrimination in an instrument that would cover areas not protected by all provincial legislation, and "serve to limit discriminatory activities on the part of governments as well." As Prime Minister, he proposed an entrenched bill of rights that "does not stop at restricting governmental action.... [But] is designed to protect rights against private action as well." 77 The Victoria Charter of 1971, however, only restricted the state, and did not affect private conduct. $^{78}$

From 1972 until 1978, language encompassing prohibition of private discrimination was considered again. ${ }^{79}$ The draft put forward in Bill C-60 in 1978, though, abandoned that idea. ${ }^{80}$ The concept had been rejected by the Canadian Bar Association in their study of the proposals for the constitution in $1978 .{ }^{81}$ Commenting on the federal government's proposals in The Constitution and the People of Canada, ${ }^{82}$ the CBA wrote that the document "goes too far in attempting to deal with private discrimination." ${ }^{, 3}$ It approved the Manitoba Law

Hogg, Constitutional Law, supra note 48 at 37-31. See also Peter W Hogg, "The Dolphin Delivery Case: The Application of the Charter to Private Action" (1986) 51:2 Sask L Rev 273 ("the Court's decision to exclude private action from the binding effect of the Charter establishes a fundamental principle of Charter interpretation. In my view, this ruling is not only technically correct but is also sound as a matter of constitutional policy" at 279). Hogg, Constitutional Law, ibid at 37-32.

McKinney, supra note 68; Stoffman, supra note 72; Greater Vancouver Transportation Authority $v$ Canadian Federation of Students - British Columbia Component, 2009 SCC 31.

"A Canadian Charter of Human Rights, The Honourable Pierre Elliott Trudeau, Minister of Justice, January 1968," in Bayefsky, vol 1, supra note 56, ch 9 at 59.

"The Constitution and the People of Canada: An Approach to the Objectives of Confederation, the Rights of People and the Institutions of Government, The Right Honourable Pierre Elliott Trudeau, Prime Minister of Canada, 1968," in Bayefsky, ibid, ch 11 at 82-83, 90-92.

"Canadian Constitutional Charter, 1971 (The Victoria Charter)," in Bayefsky, ibid, ch 18.

The final report of the Special Joint Committee on the Constitution, 1972, recommended provisions in the Charter that would address discrimination that "lies in the area of private morality and individual mores," by prohibiting discrimination in public and private employment, membership in any professional, trade, or occupational association, or in public accommodation, facilities, and services, or in owning, renting, or possessing property ("The Special Joint Committee of the Senate and the House of Commons on the Constitution of Canada, 1972," in Bayefsky, ibid, ch 19 at 238, 241, 303).

"The Constitutional Amendment Bill (Bill C-60), First Reading, June 20, 1978, Text and Explanatory Notes," in Bayefsky, ibid, ch 25.

Committee on the Constitution, The Canadian Bar Association, Towards a New Canada (Montreal: Pierre Des Marais, 1978) at 19.

Trudeau, supra note 77 at 78.

Supra note 81 at 19. 
Reform's position ${ }^{84}$ that positive legislation administered by human rights commissions was more suitable for that purpose, and that a constitutional bill of rights should deal with equality before the law. That view was echoed by Otto Lang as Minister of Justice, who conceived of the Charter as "a common agreement to restrict the powers of all governments." ${ }^{85} \mathrm{He}$ articulated the need to distinguish the protections of rights that would properly flow from constitutional entrenchment and "those which, while important, are better recognized as goals to be achieved through affirmative legislation. ${ }^{" 86}$ No subsequent draft of the Charter contained provisions dealing with private discrimination. ${ }^{87}$ In this respect the Charter that was entrenched fulfilled an orthodox role of controlling government acts and leaving laws affecting private actions to positive legislation.

\section{The Charter's (Historically) Limited Positive Rights}

The Charter restrains the state, but does it only restrain the state? Though the Charter, generally "is not in itself an authorization for governmental action," 88 it may, in protecting people from governmental interference, require the state to take positive steps. The majority in Haig noted that "a situation might arise in which, in order to make a fundamental freedom meaningful, a posture of restraint would not be enough, and positive governmental action might be required." 89 In Dunmore, the majority described conditions under which such positive steps might be required, finding the state responsible for a substantial interference with a fundamental freedom through exclusion from labour legislation of an unprotected class of persons, ${ }^{90}$ to the extent that the state "substantially orchestrates, encourages, or sustains the violation of fundamental freedoms." "The case for the state going further on the basis of a Charter right, and taking positive steps not merely to protect rights but to provide positive entitlements flowing from the Charter was perhaps most forcefully made in Justice Arbour's dissent in Gosselin v. Quebec (Attorney General). ${ }^{92}$ The majority in that case, while declining to find an entitlement to increased welfare benefits on the facts, conceded that:

Manitoba, Law Reform Commission, Report on the Case for a Provincial Bill of Rights (Winnipeg: Manitoba Law Reform Commission, 1976) at 53. The Commission generally endorsed the view that "a civilized self-respecting democracy needs built-in countervailing restraints on the power of modern elephantine government and its agencies" (ibid at 3 ).

85 The Honourable Otto E Lang, Minister of Justice, Constitutional Reform: Canadian Charter of Rights and Freedoms (Ottawa: Government of Canada, 1978) at 2.

Ibid.

87 Several parties advocated the addition of various forms of positive rights during the hearings of the Special Joint Committee on the Constitution, including many affecting private conduct. The Canadian Chamber of Commerce suggested "minimum standards of essential services" (Proceedings of SJC, supra note 44, 32nd Parl, 1st Sess, No 8 (19 November 1980) at 8. The Canadian Federation of Civil Liberties and Human Rights Associations called for an "accent on positive action" in the Charter (ibid, 32nd Parl, 1st Sess, No 21 (8 December 1980) at 9). The Submission by the Public Interest Advocacy Centre and the National Anti-Poverty Association proposed various positive rights including a right to work, a right to rest and leisure, and a right to an adequate standard of living and social security ( $\mathrm{ibid}$, 32nd Parl, 1st Sess, No 29 (18 December 1980) at A:7-A:9). The Afro-Asian Foundation of Canada called for protections against private discrimination and "the protection of places of worship of AfroAsian religious sects from vandalism and defamation" (ibid, 32nd Parl, 1st Sess, No 32 (6 January 1981) at 33). Mr. Tadeusz Gryger of the Canadian Association for the prevention of Crime advocated recognition of "the French or Swiss tradition, which extends to many other countries of Europe, which stems from Jean Jacques Rousseau and his idea of general will, where we find freedom in the collectivity and nobody can be free unless he is a member of the free community" (ibid, 32nd Parl, 1st Sess, No 24 (11 December 1980) at 52).

Hunter, supra note 67 at 156.

Haig, supra note 69 at 1039.

Dunmore, supra note 66 at paras 23-26.

Ibid at para 26.

2002 SCC 84 at paras 307-29, Arbour J, dissenting [Gosselin]. 
“[o]ne day s. 7 may be interpreted to include positive obligations. To evoke Lord Sankey's celebrated phrase in Edwards v. Attorney-General for Canada ... the Canadian Charter must be viewed as 'a living tree capable of growth and expansion within its natural limits.",93

The courts have identified various forms of positive Charter rights, and some have argued that positive entitlements have been identified too narrowly. In her dissent in Gosselin, Justice Arbour cited the right to vote, the right to trial within a reasonable time, the right to be presumed innocent, to trial by jury, to an interpreter in penal proceedings, and minority language education rights as instances in the Charter of what she termed "positive obligations of performance on the state." ${ }^{94}$ Commentators have cited sections 3, 5, 7, 10, 11 , and 14 to 23 as providing express or implied positive rights. ${ }^{95}$ All of these sections can be described as providing some sort of positive entitlement. They do so in very different ways, however. For example, section 20 creates clear, free-standing obligations on government to provide services in English or French. Other sections create positive entitlements only to persons against whom the government is acting in a certain way. There is no free-standing right to counsel, for instance. The entitlement to counsel arises via section 10(b) when the state threatens a person's liberty ${ }^{96}$ (as well as via sections 7 and $11(\mathrm{~d}$ ) as a principle of fundamental justice). ${ }^{97}$ That is to say, it is a requirement on the state constraining how the state may prosecute, if the state chooses to do so. The right to counsel is therefore a contingent obligation on the state, among other contingent obligations that constrain how the state may investigate, prosecute, or punish. As "positive rights," these are very different from the right to vote, or language rights.

Recognizing the differences between the various kinds of positive Charter rights helps to clarify the extent to which a proposed use of the Charter is truly novel, or may be inconsistent with the orthodox understanding of the Charter as a classical liberal instrument. Some positive obligations are not at all incompatible with that understanding. Although many positive obligations have been identified in the Charter, most sit comfortably within

$93 \quad$ Ibid at para 82, citing Edwards v Attorney General for Canada (1929), [1930] AC 124 at 136 (PC).

$94 \quad$ Gosselin, ibid at para 320.

95 See e.g. Brian Slattery, “A Theory of the Charter” (1987) 25:4 Osgoode Hall LJ 701; Martha Jackman, "The Protection of Welfare Rights Under the Charter" (1988) 20:2 Ottawa L Rev 257; Ian Morrison, "Security of the Person and the Person in Need: Section Seven of the Charter and the Right to Welfare" (1988) 4 J L \& Soc Pol'y 1; Andrew Petter \& Allan C Hutchinson, "Rights in Conflict: The Dilemma of Charter Legitimacy" (1989) 23:3 UBC L Rev 531; William W Black, "The Charter of Rights and Freedoms and Positive Obligations" in William Kaplan \& Donald McRae, eds, Law, Policy, and International Justice: Essays in Honour of Maxwell Cohen (Montreal: McGill-Queen's University Press, 1993 ) 298; Martha Jackman, “'Giving Real Effect to Equality:' Eldridge v. British Columbia (Attorney General) and Vriend v. Alberta" (1998) 4:2 Rev Const Stud 352; Ran Hirschl, "Negative' Rights vs. 'Positive' Entitlements: A Comparative Study of Judicial Interpretations of Rights in an Emerging NeoLiberal Economic Order" (2000) 22:4 Hum Rts Q 1060; Jamie Cameron, "Positive Obligations Under Sections 15 and 7 of the Charter: A Comment on Gosselin v. Québec" (2003) 20 SCLR (2d) 65; Cara Wilkie \& Meryl Zisman Gary, "Positive and Negative Rights Under the Charter: Closing the Divide to Advance Equality" (2011) 30 Windsor Rev Legal Soc Issues 37; Chava Schwebel, "Welfare Rights in Canadian and German Constitutional Law" (2011) 12:11 German LJ 1901; Vanessa A MacDonnell, "The Constitution as Framework for Governance" (2013) 63:4 UTLJ 624; Emmett Macfarlane, "The Dilemma of Positive Rights: Access to Health Care and the Canadian Charter of Rights and Freedoms" (2014) 48:3 J Can Studies 49; Lawrence David, "A Principled Approach to the Positive/Negative Rights Debate in Canadian Constitutional Adjudication” (2014) 23:1 Const Forum Const 41; Margot Young, "Charter Eviction: Litigating Out of House and Home" (2015) 24 J L \& Soc Pol'y 46.

$96 \quad R v$ Therens, [1985] 1 SCR 613 at 642, Le Dain J, dissenting (though the majority adopted the portion of his judgment dealing with the meaning of "detention").

${ }_{97} \quad R v G D B, 2000$ SCC 22 at para 24; Re Howard and Inmate Disciplinary Court, [1984] 2 FC 642 (FCA) at paras 89,92 . 
classical liberal constitutionalism. For example, those obligations which constrain how the state may act are entirely consistent with classical liberal constitutionalism. So are those which, following the model in Haig, are conceived as positive steps that must be taken with the aim of enhancing protections from encroachment on rights by the state. Other obligations, such as those flowing from interpretations of equality rights ${ }^{98}$ or derivative positive rights, ${ }^{99}$ have been criticized as being incompatible with a conventional understanding of the Charter's function.

Most "rights" defined in the Charter are legal protections of freedoms. People are able to speak freely: the "right to freedom of expression" in the Charter is a legal restriction on the state not to interfere with speech. ${ }^{100}$ The function of the Charter is overwhelmingly to protect people, especially minorities, from the actions of an enthusiastic majority. The Charter recognizes freedoms and guarantees that the state will not interfere with them, subject to such reasonable limits prescribed by law that are demonstrably justified in a free and democratic society. That is to say, most Charter rights are protections of "negative liberty" in that they carve out areas into which the state should not intrude. Positive rights, on the other hand, create an entitlement to receive something from the state, and a corresponding obligation on the state to provide it. Though they are the exception, ${ }^{101}$ six types of positive obligations have been recognized by the courts as flowing, in various ways, from different Charter rights. The aim of identifying these categories is to note differences between the types of positive obligations that arise. "Positive rights" (or positive obligations and entitlements) is a useful category, but it is vague. The following — quite different — kinds of positive Charter rights can be identified (in order, beginning with those that are clearly free-standing positive rights and moving to those that are less so).

\section{LANGUAGE Rights}

The language rights in sections 16 to 23 of the Charter do more than protect a freedom. They include, for instance, the right "to receive available services from [government] in English or French," 102 and "the right to have their children receive primary and secondary school instruction in that [minority] language." 103 Language rights in the Charter are something of a special case, in that protection of the rights of linguistic minorities was a

See e.g. Thomas MJ Bateman, "Liberal Versus Post-Liberal Constitutionalism: Applying the Charter to Civil Society" in FL Morton, ed, Law, Politics, and the Judicial Process in Canada, 3rd ed (Calgary: University of Calgary Press, 2002) 19 [Bateman, "Liberal Versus Post-Liberal Constitutionalism"]; Barry L Strayer, Canada's Constitutional Revolution (Edmonton: University of Alberta Press, 2013) at 261-62 [Strayer, Constitutional Revolution].

See e.g. Brian Langille, "The Freedom of Association Mess: How We Got into It and How We Can Get out of It" (2009) 54:1 McGill LJ 177 [Langille, "Freedom of Association Mess"]; Brian Langille, "Why the Right-Freedom Distinction Matters to Labour Lawyers — And to All Canadians" (2011) 34:1 Dal LJ 143 [Langille, "Right-Freedom Distinction Matters]; Brian Langille \& Benjamin Oliphant, "The Legal Structure of Freedom of Association" (2014) 40:1 Queen's LJ 249 [Langille \& Oliphant, "Legal Structure"]; Benjamin Oliphant, "Exiting the Freedom of Association Labyrinth: Resurrecting the Parallel Liberty Standard Under 2(d) \& Saving the Freedom to Strike" (2012) 70:2 UT Fac L Rev 36, especially at 48-49; Brian Langille, "The Condescending Constitution (or, the Purpose of Freedom of Association is Freedom of Association)" (2016) 19:2 CLELJ 335 [Langille, "The Condescending Constitution"]; The Honourable Justice Marshall Rothstein "Checks and Balances in Constitutional Interpretation", (2016) 79:1 Sask L Rev 1. 
distinct political impetus for the creation of the Charter, and one which was at least as important as protection of fundamental freedoms. ${ }^{104}$ The rights entail positive obligations on government to provide the specified services, and these rights are free-standing, which is to say they are not contingent on being triggered by some state action. They are the Charter's only explicit non-contingent positive obligations.

\section{OBLigations FlOWING From \\ DERIVATIVE POSITIVE RIGHTS}

The Supreme Court has held some positive obligations to be derivative of Charter rights where the absence of the obligation on the part of the state makes it impossible to exercise a Charter right, or "substantially interferes" 105 with the exercise of that right. Various positive derivative rights - rights that are held to be necessary in order to allow the exercise of other Charter rights - have been found by the courts to flow from the section 2(d) right to freedom of association, ${ }^{106}$ including the right to be included in a labour code, ${ }^{107}$ and the right to strike. ${ }^{108}$ Section 2 (d) has been held to protect the right to bargain collectively, ${ }^{109}$ and prevent exclusion from labour legislation where that exclusion would "substantially interfere" with freedom of association. ${ }^{110}$ Access to government information ${ }^{111}$ and public access to court proceedings ${ }^{112}$ have also been found to be derivative rights, flowing from section 2 (b). ${ }^{113}$

The law establishing various derivative positive Charter rights is not settled. The decisions are not unanimous. In Fraser, Justice Rothstein was highly critical of the idea that freedom of association entails a particular majoritarian model of collective bargaining. ${ }^{114} \mathrm{He}$ wrote a strong dissent in Mounted Police Association. ${ }^{115}$ Justices Rothstein and Wagner dissented in Saskatchewan Federation of Labour. ${ }^{116}$ The decisions have been the subject of academic criticism. ${ }^{117}$ Nonetheless, as the law now stands the Charter entails obligations on the state to legislate labour codes, and imposes constitutional obligations on employers to bargain in good faith and not otherwise interfere with the freedom to associate.

It is worth noting the language the majority uses in Dunmore in affirming the agricultural workers' rights. When ruling that the freedom of association right — the requirement that government not prevent people from associating with whomever they wish — includes the

See e.g. Russell, supra note 46

Mounted Police Association of Ontario v Canada (Attorney General), 2015 SCC 1 at para 71 [Mounted Police Association].

Charter, supra note 1, s 2(d).

Dunmore, supra note 66.

Saskatchewan Federation of Labour v Saskatchewan, 2015 SCC 4 [Saskatchewan Federation of Labour].

Ontario (Attorney General) v Fraser, 2011 SCC 20 [Fraser].

Dunmore, supra note 66 at para 22.

Ontario (Public Safety and Security) v Criminal Lawyers' Association, 2010 SCC 23. The criteria for establishing a positive rights claim under section 2(b) are listed in Baier v Alberta, 2007 SCC 31 at para 28, following Dunmore, ibid.

Canadian Broadcasting Corp v New Brunswick (Attorney General), [1996] 3 SCR 480.

Charter, supra note 1, s 2(b).

Supra note 109 at paras 119-294, especially at 257-69.

Supra note 105 at paras $159-270$, Rothstein J, dissenting.

Supra note 108, Rothstein and Wagner JJ, dissenting.

See e.g. Langille \& Oliphant, "Legal Structure," supra note 99. 
entitlement to be written into a labour code that binds private people and companies, the Supreme Court holds that it is requiring positive action to make the guarantee of noninterference meaningful. The majority writes, "underinclusive state action falls into suspicion not simply to the extent it discriminates against an unprotected class, but to the extent it substantially orchestrates, encourages or sustains the violation of fundamental freedoms."118 That is to say that the model of the Charter protecting our fundamental freedoms from government intrusion is honoured in principle by recognizing derivative rights (though some would say it is honoured mainly in the breach).

\section{Obligations Flowing From Voting Rights}

The democratic rights in section 3, that is "the right to vote in an election," and "to be qualified for membership" "119 are positive in form. They imply obligations on the state to organize elections and permit people to run in them. Together with the term limits in section $4,{ }^{120}$ they restrain the state by preventing a government from staying in power indefinitely without calling an election.

The purpose of the democratic rights in section 3 of the Charter has been described as "to grant every citizen of this country the right to play a meaningful role in the selection of elected representatives." 2121 Voting rights in the Charter are more than conditional or adverbial $^{122}$ requirements on the state. They require the state to take certain steps to empower citizens to do something. This power, however, is a key restraint on the state. These rights are not contingent in any sense except insofar as they cannot be exercised unless there is an election to vote in, and the Supreme Court has held that section 3 rights have the effect of obliging government to submit itself to elections. ${ }^{123}$ Section 4 specifies term limits, and the Supreme Court has held that failure to hold regular elections would violate the Charter, and failure to act on the results of an election "would entail a serious constitutional breach."124 Democratic rights include positive rights to vote. Nonetheless, as voting rights are a form of restraint on the state, they do not unsettle a theory of the Charter as a classical liberal instrument.

\section{PRescribed Contingent Obligations}

The Charter places numerous obligations on the state which are contingent on there being some state action to trigger those obligations. Some are more clearly specified than others. Many of the legal rights in sections 7 to 14 are relatively clear-cut. Rights such as the section 10 right on arrest or detention to be informed promptly of the reasons thereof, ${ }^{125}$ the section 11 right not to be compelled as a witness against oneself, ${ }^{126}$ or the section 14 right to an

Dunmore, supra note 66 at para 26.

Charter, supra note 1, s 3.

Ibid, s 4.

Haig, supra note 69 at 1031.

The terminology is from Michael Oakeshotts, On Human Conduct (Oxford: Clarendon Press, 1975) at 113.

Haig, supra note 69 at 1032.

Ibid.

Charter, supra note 1, s 10.

Ibid, $\mathrm{s} 11$. 
interpreter ${ }^{127}$ prescribe certain things quite clearly and have been subject to relatively little scrutiny as to what obligations arise in certain situations. These obligations on the state are contingent on some triggering state action. They only become obligations on the state if the state acts in some manner - usually by acting against someone in some way — triggering the relevant entitlement. Therefore, though they require positive action by the state, once a given triggering condition is met (for example, when the state conducts a search), they are essentially adverbial constraints that control how the state may act.

\section{IMPLIED CONTINGENT OBLIGATIONS}

Most contingent obligations in the Charter are not specifically enumerated, but implied by general language such as that in section 7 (the right not to be deprived of life, liberty, and security of the person "except in accordance with the principles of fundamental justice") ${ }^{128}$ and section 15 (the recognition that all are "equal before and under the law" and have a right to the "equal protection and equal benefit of the law without discrimination"). ${ }^{129}$ Specific obligations have been developed through judicial interpretation of sections 7 to 14. For example, the right to remain silent when questioned by police, the requirement on the state to obtain a warrant for a search, and the nature and extent of those rights, are not specified in the Charter but have been created through interpretation of sections $7,8,10$, and $11 .^{130}$

Claims for non-contingent entitlements have been advanced under section 7 , such as the right to adequate and accessible housing and to a minimal level of social assistance. In Gosselin, the argument was advanced, in dissenting reasons, that a positive entitlement to a minimal level of social assistance arising from section 7 would not be extraordinary, in that the Charter contains many positive entitlements. ${ }^{131}$ Any such argument, however, must acknowledge a distinction between contingent and non-contingent obligations. The freestanding entitlement to a certain level of social assistance claimed in Gosselin and Masse v. Ontario (Ministry of Community and Social Services), ${ }^{132}$ the entitlement to housing advocated in Tanudjaja v. Canada (Attorney General), ${ }^{133}$ or the entitlement to funding for out-of-country medical treatment sought in Flora v. Ontario (Health Insurance Plan,

\section{Ibid, s 14 .}

Ibid, $\mathrm{s} 7$.

Ibid, $\mathrm{s} 15$.

See e.g. $R v$ Fitzpatrick, [1995] 4 SCR 154 at paras 21-25 (the scope of protections against selfincrimination is determined by a contextual analysis); $R v$ Noble, [1997] 1 SCR 874 at para 72 (no adverse inference may be drawn from a failure to testify); $R v$ Hebert, [1990] 2 SCR 151 at 178 (section 7 entails a right to choose freely whether to make a statement to authorities); $R v$ Suberu, 2009 SCC 33 at paras 22,28 (preliminary engagement or questioning by police does not necessarily constitute an investigative detention); $R v$ Grant, 2009 SCC 32 at para 44 (detention involves some form of physical or psychological compulsion or restraint); Hunter, supra note 67 at 160 (the Charter provides preemptive protection against unjustified searches); Rv Feeney, [1997] 2 SCR 13 (agents of the state must obtain a search warrant to enter a dwelling house except when in hot pursuit); $R v$ Tessling, 2004 SCC 67 at para 18 (an inspection will constitute a search when it involves information in which a person has a reasonable expectation of privacy); $R v$ Patrick, 2009 SCC 17 at paras 36-38 (whether an expectation of privacy is reasonable will depend on the totality of the circumstances).

Gosselin, supra note 92 ("[a]s a theory of the Charter as a whole, any claim that only negative rights are constitutionally recognized is of course patently defective" at para 320, Arbour J, dissenting). See also Fraser, supra note 109 at para 72.

Gosselin, ibid; Masse v Ontario (Ministry of Community and Social Services) (1996), 134 DLR (4th) 20 (Ont Gen Div), leave to appeal to CA refused (1996), 89 OAC 8 at $\mathrm{n} 1$, leave to appeal to SCC refused, 25462 (5 December 1996).

2014 ONCA 852, leave to appeal to SCC refused, 36283 (22 June 2015). 
General Manager), ${ }^{134}$ would be unlike any of the other (contingent) entitlements that flow from sections 7 to 14 .

Judicial interpretation of the equality rights in section 15 has attracted charges that the courts have created new entitlements and drawn what is properly a legislative function into the process of judicial review. ${ }^{135}$ For instance, one of the Charter's key composers, Strayer, writes:

In Isaiah Berlin's analysis, the right not to be discriminated against is a "negative right" that deserves legal protection to prevent the state from actively harming certain classes of persons. That is what we originally thought we were trying to do with section 15. In the Berlin analysis, "positive rights" involve entitlements that require the state to act in favour of particular individuals or groups. We did not think we were creating these in the sense of imposing judicially enforceable obligations on the state to spend money on entitlements defined by the courts. ${ }^{136}$

Remedies provided by the Supreme Court following review under section 15 have certainly had the effect of extending benefits under the law to those whom the courts deemed to be improperly excluded. For example, section 15(1) has been used to provide paternity benefits to natural parents, ${ }^{137}$ to extend the definition of "spouse" in old age security legislation to include same-sex partners, ${ }^{138}$ to provide sign language interpreters under provincial Medicare, ${ }^{139}$ to include sexual orientation as a prohibited ground of discrimination in provincial human rights' law, ${ }^{140}$ and to include unmarried same-sex couples in provincial family law legislation so as to allow access to court-ordered support payments. ${ }^{141}$ Does this mean the Charter, and particularly section 15 , is responsible for creating obligations on the state out of whole cloth? The test of a breach of section 15 is whether the state has acted in a way that creates a discriminatory distinction based on an enumerated or analogous ground, where a "discriminatory distinction" is one that creates an arbitrary disadvantage or perpetuates prejudice or stereotyping. ${ }^{142}$ The test addresses whether state action is equitable. The Supreme Court has also addressed cases where a form of inaction - leaving a group out unfairly - has created inequality. ${ }^{143}$ The crucial issue remains how the state has acted. This is clearly demonstrated in Auton (Guardian ad litem of) v. British Columbia (Attorney

\section{ONCA 538.}

See e.g. FL Morton \& Rainer Knopff, The Charter Revolution and the Court Party (Peterborough: Broadview Press, 2000); Christopher P Manfredi, Judicial Power and the Charter: Canada and the Paradox of Liberal Constitutionalism, 2nd ed (Don Mills, Ont: Oxford University Press, 2001); Robert Ivan Martin, The Most Dangerous Branch: How the Supreme Court of Canada has Undermined our Law and our Democracy (Montreal: McGill-Queen's University Press, 2003) at 120-23; James B Kelly, Governing with the Charter: Legislative and Judicial Activism and Framers' Intent (Vancouver: UBC Press, 2005); Philip Slayton, Mighty Judgment: How the Supreme Court of Canada Runs Your Life (Toronto: Allen Lane Canada, 2011); Emmett Macfarlane, Governing From the Bench: The Supreme Court of Canada and the Judicial Role (Vancouver: UBC Press, 2013).

Strayer, Constitutional Revolution, supra note 98 at 261-62 [footnotes omitted].

Schachter v Canada, [1992] 2 SCR 679.

Egan v Canada, [1995] 2 SCR 513.

Eldridge v British Columbia (Attorney General), [1997] 3 SCR 624 [Eldridge].

Vriend, supra note 66.

$M v H,[1999] 2$ SCR 3.

Law v Canada (Minister of Employment and Immigration), [1991] 1 SCR 497 at 524; R v Kapp, 2008 SCC 41 at para 17 [Kapp]; Withler v Canada (Attorney General) 2011 SCC 12 at para 30; Quebec (Attorney General) v A, 2013 SCC 5 at paras 324, 418; Kahkewistahaw First Nation v Taypotat, 2015 SCC 30 at paras 16, 18 [Taypotat].

Vriend, supra note 66 at paras 58-88. Cf Dianne Pothier, "The Sounds of Silence: Charter Application When the Legislature Declines to Speak" (1996) 7:4 Const Forum Const 113. 
General), where the Supreme Court distinguishes that case - a claim for intensive behavioural therapy for autistic children - from Eldridge, in which the Supreme Court found the failure to provide interpreters for deaf patients to unfairly exclude them from medical treatment:

Eldridge was concerned with unequal access to a benefit that the law conferred and with applying a benefitgranting law in a non-discriminatory fashion. By contrast, this case is concerned with access to a benefit that the law has not conferred. ${ }^{144}$

The majority in Eldridge had held that "once the state does provide a benefit, it is obliged to do so in a non-discriminatory manner." 145 In Kapp, the Supreme Court held that section 15(2) creates an exception to 15(1) to enable programs aimed at assisting a disadvantaged group. ${ }^{146}$ Section $15(2)$, then, does not so much create any positive contingent obligations, but enables governments to enact positive legislation without being caught by section 15(1). ${ }^{147}$ In Vriend, addressing the exclusion of sexual orientation as a recognized ground of potential discrimination under Alberta's Individual's Rights Protection Act, ${ }^{148}$ the majority found the Act's underinclusivity, and "the deliberate decision to omit sexual orientation" were acts of the legislature to which the Charter could apply. ${ }^{149}$

The Supreme Court's decisions in even the most "activist" of section 15 cases honour the basic principles of liberal constitutionalism. At times, the conceptual line between a robust equality requirement and positive "derivative" right may be difficult to discern. A derivative right is a form of implied obligation that is intended to buttress a right or remove a particular interference with it, rather than flowing directly from it. As Brian Langille has argued, Dunmore could have achieved a very similar result in requiring protection for agricultural workers via an equality rights analysis. ${ }^{150}$ While the Supreme Court's decisions in cases such as Vriend have drawn criticism, identifying an implied Charter obligation through interpretation of equality rights, as opposed to establishing new derivative rights, would maintain a more consistent model of Charter rights and obligations.

\section{ASSUMED CONTINGENT OBLIGATIONS}

Governments have often taken certain steps, without specifically being required to do so by the courts, to ensure particular government actions are compliant with the Charter. The anticipation by lawmakers of a Charter issue, or the adjustment of legislation when it has been struck down by the courts, is part of the process of "Charter dialogue" described by

2004 SCC 78 at para 38 [Auton], citing Eldridge, supra note 139.

Eldridge, ibid at para 73, citing Tétreault-Gadoury $v$ Canada (Employment and Immigration Commission), [1991] 2 SCR 22; Haig, supra note 69 at 1041-42; Native Women's Assn of Canada $v$ Canada, [1994] 3 SCR 627 at 655; Miron v Trudel, [1995] 2 SCR 418.

Supra note 142 .

See discussion in Part III.A, below. A concurring minority opinion applied section 25 to achieve the same result (as Kapp involved aboriginal fishing rights), ibid at paras 76-123.

RSA 1980, c I-2.

Vriend, supra note 66 at para 62.

See Langille, "Freedom of Association Mess," supra note 99; Langille, "The Condescending Constitution," supra note 99. 
Hogg and Allison Bushell. ${ }^{151}$ Where lawmakers attempt to mitigate a possible Charter infringement, they sometimes assume positive obligations in doing so. For example, in Ramsden v. Peterborough (City), the Supreme Court found the city's absolute ban on postering to be an unconstitutional restraint on freedom of expression. ${ }^{152}$ In response, cities across Canada have built public bulletin boards or installed postering collars around downtown utility poles, in order to achieve purposes including controlling litter and keeping public utility poles free of clutter while allowing space for expression through postering. Though the necessity of these steps flowed from the constitutional protection of a negative liberty (the right to freedom of expression), and they were not required by the Supreme Court as a remedy under section 24 , they can reasonably be seen as a form of contingent positive obligation in that they were a response to a Charter challenge. Where cities want to control postering, some expense may be required in order to respect freedom of expression. The collars and bulletin boards are therefore a result of contingent positive obligations that have arisen from the Charter. They are an example of laws being modified after the courts have struck legislation without reading it down or reading in some specific alteration that would render the law constitutional. When this occurs, or when laws are written in a way that mitigates the effect of any infringement of Charter rights, or are proactively modified in anticipation of a Charter challenge, it might be said that the state has assumed contingent obligations out of respect for the Charter.

The aim here is not to create a definitive catalogue of positive rights in the Charter. The aim is rather to demonstrate that though it is true that many positive entitlements can be found, freestanding positive rights are exceptional. The last four categories of positive rights described above - the last five, if it is accepted that derivative rights remain essentially protections of freedoms - function as restraints on the state, consistent with an orthodox understanding of the role of an entrenched bill of rights. With the significant exceptions of language rights and, more recently, derivative rights mainly within labour law, the Charter's positive rights are contingent: they control how the state must act when it chooses to do certain things that put other rights at risk. It is possible that a seventh category of positive rights is emerging from the growth of derivative rights and expansive interpretations of other rights: what might be considered legislated addenda to the Charter, or constitutionalized legislation, but that question is beyond the scope of this article.

\section{NOVEL USES OF THE CHARTER}

Recent developments in administrative law have seen greater jurisdiction accorded to administrative tribunals to interpret and apply the Charter, and greater deference given to those tribunals' decisions. In Slaight Communications Inc. v. Davidson, the Supreme Court held that a decision-maker "exercising delegated powers does not have the power to make

151 Peter W Hogg \& Allison A Bushell, "The Charter Dialogue Between Courts and Legislatures (Or Perhaps the Charter of Rights Isn't Such a Bad Thing After All)" (1997) 35:1 Osgoode Hall LJ 75; Peter W Hogg, Allison A Bushell Thornton \& Wade K Wright, "Charter Dialogue Revisited — or 'Much Ado About Metaphors"' (2007) 45:1 Osgoode Hall LJ 1. Dialogue theory has been the subject of much critical attention. See e.g. Grant Huscroft \& Ian Brodie, eds, Constitutionalism in the Charter Era (Markham: LexisNexis, 2004) at Part I; Kent Roach, The Supreme Court on Trial: Judicial Activism or Democratic Dialogue, revised ed (Toronto: Irwin Law, 2016). 
an order that would result in an infringement of the Charter." ${ }^{153}$ In Baker v. Canada (Minister of Citizenship and Immigration), the Supreme Court affirmed that administrative discretion must be exercised in a manner consistent with the Charter. ${ }^{154}$ In Nova Scotia (Workers' Compensation Board) v. Martin; Nova Scotia (Workers' Compensation Board) v. Laseur, in 2003, the Supreme Court held that any government agency with the power to determine questions of law has the jurisdiction to determine the constitutionality of any legislative provision it enforces. ${ }^{155}$ In Dunsmuir v. New Brunswick, in 2008, the Supreme Court held that administrative tribunals' decisions interpreting their own statutes should normally be reviewed on a reasonableness standard. ${ }^{156}$ In $R$. v. Conway, in 2010, the Supreme Court confirmed that administrative tribunals have jurisdiction to grant Charter remedies if they have express or implied jurisdiction to decide questions of law. ${ }^{157}$ In the 2012 Doré decision, the Supreme Court held that where a tribunal balances Charter values in the exercise of its statutory discretion, the decision will be subject to review on a reasonableness standard. ${ }^{158}$ Before Doré, the courts applied a correctness standard in reviewing the exercise of administrative discretion that infringed the Charter in a way that was not a reasonable limit prescribed by law and demonstrably justifiable in a free and democratic society. Such infringements were treated as jurisdictional errors that would have no force and effect, on the assumption that Parliament would not have delegated the power to infringe the Charter to an adjudicator exercising a statutory discretion. ${ }^{159}$ The Supreme Court in Doré noted ${ }^{160}$ the critical reaction to the application of an Oakes section 1 approach to Charter issues engaged by an administrative decision in Multani v. Commission scolaire Marguerite-Bourgeoys. ${ }^{161}$ In Doré, the Supreme Court held that decisions of a tribunal taken using the "more flexible administrative approach to balancing Charter values" "162 should not attract a higher standard of review only because Charter interests are implicated. ${ }^{163}$ Hence, though the constitutionality of hate speech legislation, for example, was considered via an Oakes proportionality analysis in Whatcott, the Saskatchewan Human Rights Tribunal's application

[1989] 1 SCR 1038 at 1078 [Slaight Communications].

[1999] 2 SCR 817 at 853-54.

2003 SCC 54 at paras 27-29.

2008 SCC 9 [Dunsmuir]. Dunsmuir held that, aside from deference that might arise from a privative clause or settled law on an issue, there is a rebuttable presumption of deference except on a jurisdictional issue or an issue of central importance to the legal system and outside the specialized area of expertise of the decision-maker (ibid at paras 51-64). True questions of jurisdiction, however, were held in ATCO Gas and Pipelines Ltd v Alberta (Utilities Commission), 2015 SCC 45 to be, "if they exist ... at all, an issue yet unresolved by the Court ... rare and exceptional" (ibid at para 27). Mouvement laïque québécois v Saguenay (City), 2015 SCC 16 [Mouvement läque québécois] affirmed that the presumption of review on a reasonableness standard for questions of law regarding interpretation of a tribunal's home statute may be rebutted via contextual analysis of whether jurisdiction on an issue was intended to be protected. A majority of the Supreme Court confirmed in Canadian Broadcasting Corp v SODRAC 2003 Inc, 2015 SCC 57 [SODRAC] that different standards may be applied to different aspects of a Tribunal's decision.

2010 SCC 2 at paras $81-82$.

Supra note 8.

Slaight Communications, supra note 153 at 1081.

Doré, supra note 8 at para 33 .

2006 SCC 6.

Doré, supra note 8 at para 37.

Ibid at para 45. For a more complete description of the progression, see Matthew Lewans, "Deference and Reasonableness since Dunsmuir" (2012) 38:1 Queen's LJ 59; Matthew Lewans, "Administrative Law, Judicial Deference, and the Charter" (2014) 23:2 Const Forum Const 19; Lorne Sossin \& Mark Friedman, "Charter Values and Administrative Justice" (2014) 67 SCLR (2d) 391; Audrey Macklin, "Charter Right or Charter-Lite?: Administrative Discretion and the Charter" (2014) 67 SCLR (2d) 561; Paul Daly, "The Scope and Meaning of Reasonableness Review" (2015) 52:4 Alta L Rev 799 [Daly, "Reasonableness Review"]; Mary Liston, "Administering the Charter, Proportioning Justice: ThirtyFive Years of Development in a Nutshell" (2017) 30:2 Can J Admin L \& Prac 211. 
of the law was reviewed on a reasonableness standard, though the Tribunal's decision engaged Charter rights. ${ }^{164}$

Once administrative decision-makers are charged with reasonably balancing "the Charter protections at play," 165 the question arises as to whom the Charter protects. Tribunals do not always deal only with the rights and interests of one person or business in relation to the state (as does a property assessment board, for example). The decisions of many administrative decision-makers - for example, human rights tribunals, labour boards, landlord-tenant boards, professional regulatory bodies, and arguably custody review boards ${ }^{166}$ — affect more than one private party. Charter protections, then, or Charter "guarantees,"167 "values,"168 or "interests," 169 might be considered as they affect, for instance, either an applicant or a respondent at a human rights tribunal. The duty to give effect "as fully as possible to the Charter protections at stake given the particular statutory mandate,"170 (as the test is formulated in Loyola) produces a duty, in some cases, to consider Charter values that support state intervention, when a decision-maker's analysis draws on cases that identify Charter values ${ }^{171}$ or Charter rights ${ }^{172}$ as supporting positive legislation. Neither Doré nor Loyola explicitly enjoins decision-makers to do this, but arguably, it necessarily follows. This is what has occurred in cases such as Ismail and Brandt Tractor (discussed below). ${ }^{173}$ This is a key distinction between a proportionality analysis under Oakes and the more liberal balancing prescribed by Doré and Loyola. An Oakes analysis considers whether a law or act by a state agent places a proportionate and justifiable limitation on Charter rights. It is a legal test of constitutionality rather than a prescriptive guide for the exercise of discretion. It tests legislation or actions against the restraints of the Charter. Sometimes this involves genuine conflicts between different Charter restraints on the state, such as the conflict between freedom of religion and the right to full answer and defence dealt with in N.S. ${ }^{174}$ In those cases, Charter interests have necessarily weighed on both sides of an issue. $D / L$ balancing, however, invites to a much greater extent consideration of how Charter rights, values, and protections may weigh on the side of state action. When they do, the role of the Charter in empowering the state, governing private relations, and in supporting positive entitlements, expands. The cases described below illustrate the extent to which this has occurred so far.

Whatcott, supra note 16 at paras 166-68.

Doré, supra note 8 at para 57.

So, for example, there are provisions for the attendance of a victim or a victim's family member as an observer at a review hearing under the Ontario Corrections and Conditional Release Act, SC 1992, c 20, s 5.1 .

Doré, supra note 8 at para 3.

Ibid at para 24.

Ibid at para 45.

Loyola, supra note 9 at para 39.

See e.g. Edmonton Journal v Alberta (Attorney General), [1989] 2 SCR 1326 at 1355-56; Canada (Human Rights Commission) v Taylor, [1990] 3 SCR 892 at 920 [Taylor]; Keegstra, supra note 70 at 758; $R$ v Zundel, [1992] 2 SCR 731 at 820 [Zundel]; BC Health Services, supra note 30 at para $80 \mathrm{ff.}$ Whatcott, supra note 16 (see discussion in Part III.A, below); Dunmore, supra note 66 at paras 21, 26, 30, 48; BC Health Services, ibid at para 86; Fraser, supra note 109 at paras 40, 51, 65, 67-68, 70; B(R) $v$ Children's Aid Society of Metropolitan Toronto, [1995] 1 SCR 315 at $433[B(R)]$. In a concurring minority opinion, of Justices Iacobucci and Major, $B(R)$ states that the Charter should protect children from private action as well as state action - the Charter is thereby deployed in support of child welfare legislation.

Ismail, supra note 15; Brant Tractor, supra note 19.

$R v N S, 2012$ SCC 72 [NS]. 


\section{A. Deploying The Charter in Support of State Action}

A decision-maker is bound, within the $D / L$ framework, to apply Charter values in the exercise of his or her discretion, and strike a proportionate balance between the protections and statutory objectives at stake. ${ }^{175}$ Fundamental values must always be considered. ${ }^{176}$ The fundamental Charter values that underpin each right assist in determining the extent of any infringement in a given administrative context. ${ }^{177}$ The administrative decision-maker will receive deference in his or her consideration of whether statutory aims and fundamental Charter values justify limitation of Charter protections where that decision-maker "has the necessary specialized expertise and discretionary power in the area where the Charter values are being balanced." 178

This framework encourages a decision-maker to draw on Charter rights and values in support of a decision to exercise the power provided by a statutory mandate. For example, in Brand Tractor, the British Columbia Labour Relations Board applied the Supreme Court's finding in $B C$ Health Services that the collective bargaining process itself is protected by section 2(d) freedom of association rights ${ }^{179}$ to hold that a "bright line" test for preventing partial decertification during a labour dispute reflected a balance between the rights of "all parties involved." "The Board held, recognizing that the "majoritarian principle is a fundamental principle of the [Labour] Code," 181 that the "bright line" test was "consistent with Charter values [in giving] considerable weight to the value of collective bargaining and the avoidance of industrial instability in the workplace balanced against the right of employees not to associate." 182 In other words, section 2(d) of the Charter was used to uphold a majoritarian principle and require certain employees to remain in their bargaining group. Similar reasoning was recently upheld on judicial review by the Federal Court of Appeal in Wsáneć School Board. ${ }^{183}$

In Ismail, ${ }^{184}$ the British Columbia Supreme Court reviewed a decision of British Columbia Human Rights Tribunal concerning a complaint brought under provincial hate speech legislation by a patron at a nightclub. The patron had been insulted by an emcee in language that attacked her sexual orientation. The Court held, applying Doré, that "[ $\mathrm{t}]$ he statutory objective of eliminating discrimination, grounded in the Charter value of equality, must be balanced with the severity of the interference with the Charter value of freedom of expression." 185 State regulation of speech through anti-discrimination legislation was held to be "in pursuit of another Charter-protected value: equality." 186

Loyola, supra note 9 at para 80

Doré, supra note 8 at para 35.

Loyola, supra note 9 at para 36

Doré, supra note 8 at para 52.

BC Health Services, supra note 30.

Brandt Tractor, supra note 19 at paras 47, 97,100, 103.

Ibid at para 100 . The Charter is also explicitly weighed on the side of majoritarianism as instantiated in provincial labour legislation for the purposes of a $D / L$ analysis involving the "bright line" date of application test for certification in Labourers' International Union of North America v Govan Brown \& Associates Ltd, 2018 CanLII 27199 (Ont Labour Relations Board) at paras 81-83, 96, 136, 139, 150. Brandt Tractor, ibid at para 103.

Supra note 20.

Supra note 15.

Ibid at para 325. See also paras 185, 200, 211,340. The Court cited Whatcott, supra note 16 at para 200 in support of this proposition.

Ismail, ibid at para 336. 
The Supreme Court applied Charter equality rights in support of state action against discrimination in Whatcott. ${ }^{187}$ The Supreme Court addressed both the constitutionality of Saskatchewan's hate speech legislation and the reasonableness of the Tribunal's decision regarding discriminatory pamphlets delivered to homes in Saskatoon. The Supreme Court did not apply the $D / L$ framework to the Tribunal's decision, as the original decision was made in 2005, before Doré was decided in 2012. In addressing the Charter challenge to the hate speech legislation, however, the Supreme Court affirmed the principle from cases such as Taylor that the Charter value of equality gives weight to the aims of hate speech legislation. In Taylor, sections 15 and 27 of the Charter were said to "magnify the weightiness" 188 of the regulation, in Keegstra, they were said to "strongly buttress" the hate speech law, ${ }^{189}$ and in Zundel to "emphasize the laudable ... aim" of the law. ${ }^{190}$ In Whatcott the Supreme Court went further, ${ }^{191}$ stating that the hate speech legislation flowed from (and implying it might be considered an instantiation of) the Charter equality right for the purposes of its section 1 analysis. The majority framed the section 1 analysis as a "balancing of competing Charter rights"; ${ }^{192}$ specifically, as balancing the fundamental values underlying freedom of expression "with competing Charter rights and other values essential to a free and democratic society, in this case, a commitment to equality and respect for group identity and the inherent dignity owed to all human beings: s. 15 of the Charter and R. v. Oakes."193 Freedom of expression is to be weighed against "competing Charter rights," 194 which is to say "balancing between freedom of expression and equality rights." 195 The Supreme Court also weighed freedom of religion rights against Charter equality rights. ${ }^{196}$ In placing the weight of Charter equality rights behind anti-discrimination legislation, the Supreme Court developed the equality right in a significant way.

Chief Justice McLachlin described equality as "the most difficult right"197 guaranteed in the Charter, as "the Leviathan of rights" 198 which "has humbled the most sophisticated legal minds. ${ }^{199}$ In Andrews v. Law Society (British Columbia), ${ }^{200}$ Justice McIntyre wrote that equality "is an elusive concept and, more than any of the other rights and freedoms guaranteed in the Charter... lacks precise definition." ${ }^{201}$ The dissent in TWv. LSBC at the Supreme Court made this point more sharply: "equality in an absolute sense is... perfectly compatible with a totalitarian state, being easier to impose where freedom is limited."202 Justice McIntyre noted that the section 15 equality right is "not a general guarantee of equality; it does not provide for equality between individuals or groups within society in a

Supra note 16.

Taylor, supra note 170 at 920; cited also in Ross v New Brunswick School District No 15, [1996] 1 SCR 825 at para 97.

Supra note 70 at 758 .

Supra note 171 at 820 .

See Derek James From, "Whatcott: The Redaction of the Taylor Dissent" (2014) 51:3 Alta L Rev 659.

Whatcott, supra note 16 at paras 66-67.

Ibid at para 66. This passage is cited in Ismail, supra note 15 at para 200.

Whatcott, ibid at paras 112-14.

Ibid at para 145 .

Ibid at para 161 .

Beverly McLachlin, "Equality: The Most Difficult Right" (2001) 14 SCLR 17.

Ibid at 19 .

Ibid.

[1989] 1 SCR 143 [Andrews].

Ibid at 164 .

Supra note 21 at para 310. 
general or abstract sense." 203 Since Andrews, considerable jurisprudence has developed on the application of the section 15 guarantees of equal protection and benefit of the law. Equality has been identified by the Supreme Court as a Charter value, allowing considerable scope for interpretation. ${ }^{204}$ The growth and expansion of section 15 rights to support positive state action in this manner, however, had not crystalized before Whatcott. The majority in Kapp held that section 15(2) "preserves the right of governments"205 to develop programs to help disadvantaged groups improve their situation. In this way, section 15(2) enables governments to "pro-actively combat existing discrimination through affirmative measures." ${ }^{206}$ The sections work together to promote substantive equality, with section 15(2) stating that section 15(1) cannot be read to prevent the government taking positive steps to help a disadvantaged group. ${ }^{207}$ Section 15 (2) does not provide positive rights, but disengages section 15(1) for the purposes of affirmative action. The majority in Kapp stipulated that "laws designed to restrict or punish behavior would not qualify for s. 15(2) protection."208 In Whatcott, the Supreme Court held that certain conduct can be punished by the state in order to promote equality. ${ }^{209}$ The application of the equality right was further expanded, in Whatcott, to support state action within a proportionality analysis, rather than, as in Kapp, "enabling" 210 action by creating an exception for section 15(1) protections. Following Whatcott, the Charter equality right, and equality as a Charter value, have great potential within the $D / L$ framework to augment and justify state action, not only through human rights legislation, but in any case where an administrative decision-maker might take steps within their jurisdiction to enhance equality.

The interpretation of the equality right in Whatcott provides a fulcrum on which the $D / L$ lever might bear the weight of novel uses of Charter equality rights. Equality as a Charter right or value could provide leverage in favour of state action when administrative discretion is being exercised under many different laws. Almost all legislation and regulation is remedial. Laws regulating trade, banking, health, education, policing, safety, marketing, housing, labour, social assistance, and human rights all address inequitable deprivations, reduce disparities in access to services, provide equal protection from exploitation, or lessen inequalities of bargaining power in one way or another. Equality as a Charter right that supports positive legislation, or as a Charter value that may be invoked as suits the context, is broad enough to provide a justification with a universal adaptor for many kinds of state action. Following the interpretation in $B C$ Health Services and the related labour "derivative rights" cases, the Charter right to freedom of association provides another support for the exercise of discretion in favour of a majoritarian principle. These Charter rights and values, invoked in a reasonable manner, may provide versatile justifications for the exercise of power by the state. As positive applications of the Charter become further entrenched in our jurisprudence, decision-makers may find it prudent to find a Charter right or value to weigh

Andrews, supra note 200 at 163 . Justice McIntyre was dissenting in part, but with the majority "in complete agreement" on this point (ibid at 151).

BC Health Services, supra note 30 ("[h]uman dignity, equality, liberty, respect for the autonomy of the person and the enhancement of democracy are among the values that underlie the Charter" at 81 ). Supra note 142 at para 16.

Ibid at para 25.

Ibid at paras $37-38$

Ibid at para 54. Justice Bastarache, concurring in the result, applied section 25 in an equivalent manner, to prevent native rights from being curtailed by operation of section $15(1)$.

Whatcott, supra note 16 at paras 58-59, 66-67, 104, 111, 145, 151, 154, 161-62, 164, 169.

Kapp, supra note 142 at paras $25,37$. 
on the side of state action to buttress the reasonableness of an otherwise rights-infringing decision. This incentive may generate further novel and progressive uses of Charter rights.

\section{B. Applying the Charter to Private Conduct}

Brand Tractor, Wsáneć School Board, and Ismail demonstrate how the weight of the Charter can be placed behind the actions of the state through a $D / L$ balancing analysis of competing interests. In those cases, sections 2(d) and 15 of the Charter act to affect the conduct of private individuals: preventing them from leaving the union, forming a separate bargaining group, or speaking as they wish. The application of Charter rights and values to the exercise of administrative discretion in such a way that the Charter encourages action affecting an individual, rather than shielding a person from state power, challenges an orthodox conception of the Charter. The extent to which it does so will vary depending on the context and type of administrative decision.

In some contexts, the application of $D / L$ balancing to the exercise of administrative discretion provides a method for approaching a genuine conflict between different restraints on the state. It is necessary to distinguish between cases where the Charter encourages action against a group or individual, and those cases where the Charter merely restrains a decisionmaker whose actions will necessarily have consequences for individuals. Sometimes the state must act in circumstances where at least one Charter restraint must be compromised to some extent. For example, the decisions of the Law Societies in British Columbia and Ontario regarding the accreditation of Trinity Western University ${ }^{211}$ involved a tension between two restraints. Trinity Western is a private evangelical Christian university that asked students to sign a Community Covenant that does not recognize same-sex marriage. ${ }^{212}$ The Law Societies (holding statutory authority to recognize law degrees for the purposes of admission to a provincial bar) can either accredit or not accredit. Refusing to accredit effectively discriminates against the university on the basis of religious belief contrary to section 2(a) of the Charter. ${ }^{213}$ The effect of refusing accreditation is to deny members of a voluntary religious association, whose beliefs require something other than perfect secularism in postsecondary education, the opportunity to go to law school if the religion's tenets do not sufficiently coincide with Charter values. Accrediting, on the other hand, improperly discriminates against LGBTQ persons contrary to section 15 of the Charter, creating inequality of access to law school and harming dignity by endorsing discrimination. ${ }^{214}$

$211 T W v$ LSBC CA, supra note 21; TW $v$ LSUC CA, supra note 21. The similar case in Nova Scotia (Nova Scotia Barristers' Society v Trinity Western University, 2016 NSCA 59) involved a significantly different statutory framework and was resolved on the jurisdictional issue.

Following the decision of the Supreme Court of Canada, Trinity Western University announced that its covenant would no longer be compulsory. See Cristin Schmitz, "TWU Says Faith-Based Ethics Code That Discriminates Against LGBTQ Students Is No Longer Compulsory," The Lawyer's Daily (14 August 2018), online: $<$ https://www.thelawyersdaily.ca/articles/7122/twu-says-faith-based-ethics-codethat-discriminates-against-lgbtq-students-is-no-longer-compulsory->.

213 As the appellate courts held in both cases: TW 2 LSBC CA, supra note 21 at paras 102-107, 167-69; TW v LSUC CA, supra note 21 at paras 98-101.

214 Though the British Columbia and Ontario courts differed in their assessments of the degree of discrimination accreditation would create (and therefore differed in their assessments of the reasonableness of the $D / L$ balancing performed by the respective law societies), both province's appeal courts acknowledged that accreditation would be to some degree discriminatory: TW $v$ LSBC CA, ibid at paras 171-72; TW $v$ LSUC CA, ibid at paras 115-19. It may be significant that the Ontario Court of Appeal had "no hesitation" in finding the university's admissions policy and Community Covenant (as opposed to the effects of potential accreditation) to be discriminatory "contrary to s. 15 of the Charter" (ibid at para 115). Even in the context of a genuine conflict of constitutional restraints on a decisionmaker exercising statutory discretion, $D / L$ balancing seems to invite the spread of Charter standards to private conduct. 
The majority at the Supreme Court, in restoring the decision of the Law Society of British Columbia not to accredit and upholding the decision of the Law Society of Upper Canada not to accredit, generally preserved the model of section 15 of the Charter restraining the state from condoning discrimination or creating inequality of access to education. ${ }^{215}$ In addressing the Charter rights and values at stake, however, the Court also found that section 15 can support something more than mere restraint. For example, though the decision not to accredit Trinity Western by the Law Society of British Columbia was effected by a vote of the membership, ${ }^{216}$ the Court imputed reasons to the Law Society's decision that included "promoting equality" and "supporting diversity." 217 The Court then found, citing Loyola, that promoting equality and diversity is supported by the shared fundamental values found in instruments including the Charter. ${ }^{218}$ The Supreme Court thereby reaffirmed that section 15 of the Charter may be invoked to support the use of statutory discretion to take positive steps to promote equality.

Decisions by school boards provide another context involving genuine conflicts of Charter restraints on administrative decision-makers. Bonitto v. Halifax Regional School Board $^{219}$ involved a parent's request to distribute religious tracts at an elementary school. There is a conflict, in this situation, between the Board's duty to respect freedom of expression (section 2(b)) and its duty of neutrality regarding religion (section 2(a)) which restrains the Board from allowing proselytization on school grounds. The effect of the decision curtailed Bonitto's freedom of expression, but only because the Board would have been responsible for allowing his expression on school grounds where it would affect the rights of others. The situation was similar in ET v Hamilton-Wentworth ${ }^{220}$ which involved a parent requesting extensive religious accommodation to allow him to remove his child from instruction on matters including "discussion or portrayals of homosexual/bisexual conduct and relationships and/or transgenderism as natural, healthy or acceptable," "moral relativism," and "environmental worship."221 Justice Sharpe found that such accommodation was not compatible with the Board's "statutory mandate to provide an inclusive and tolerant educational environment, one that respects the principles of equality enshrined in s. 15 of the Charter."222 The requested accommodation was also found to conflict with the Board's statutory duty to provide "a respectful and accepting climate for all children," ${ }^{223}$ which also could be seen to flow from section 15. In this regard, the Board was respecting a Charter restraint in refusing the accommodation.

$D / L$ balancing may also use a Charter right or value to justify a decision in a way that employs the Charter as something other than a restraint. In Brand Tractor, Wsáneć School Board, and Ismail, the Charter operates as something other than a restraint to prevent decertification or creation of a separate bargaining unit, and to proscribe improper speech. In Ismail, the Charter aligns with the statutory objectives of the positive human rights

$T W v L S B C$ SCC, supra note 21 at paras 39,47, 103. See also ibid at para 137, McLachlin CJC concurring; TW $v$ LSUC SCC, supra note 21 at paras 21-27.

$T W v L S B C$ SCC, ibid at paras 48-50.

Ibid at para 40 .

Ibid at paras $41,46,104-105$.

2015 NSCA 80, leave to appeal to SCC refused, 36644 (18 February 2016).

Supra note 25.

Ibid at para 2 .

Ibid at para 40.

Ibid. 
legislation. In these cases, the "Charter-protected value" 224 of equality does not operate as a restraint to ensure all are "equal before and under the law" with "equal protection and equal benefit of the law without discrimination." 225 Instead, it invigorates positive remedial legislation that applies to private conduct.

Charter rights and values are also relevant in campus speech cases. University speech cases do not always involve the $D / L$ framework, as not all acts restricting speech on campus involve the exercise of a statutory authority. Universities may fall within the ambit of the Charter when they exercise a statutory authority, perform activities that are governmental in nature, or act under government control or influence. ${ }^{226}$ The Charter does not always apply to disciplinary proceedings. ${ }^{227}$ In Pridgen $v$. University of Calgary, ${ }^{228}$ however, the Charter was held to apply to disciplinary proceedings against students under Alberta's PostSecondary Learning Act. ${ }^{229}$ The initial hearing in Pridgen was prior to Doré. The Court found that the university failed to proportionately consider the student's right to freedom of expression in relation to his alleged defamatory comments online, which were held to be contrary to the university's Student Misconduct Policy's objectives of "maintaining a learning environment where there is respect and dignity for all." 230 Here there would be opportunity, under the $D / L$ framework, for a decision-maker to consider the Charter equality values inherent in the university's misconduct policy. ${ }^{231}$

In Wilson v. University of Calgary Board of Governors, ${ }^{232}$ which was also a PSLA case, Doré was applied to overturn a disciplinary decision against students who had failed to comply with direction regarding their pro-life display. Similar facts produced a different result in British Columbia Civil Liberties Assn. v. University of Victoria, ${ }^{233}$ where a pro-life group was refused use of campus space. The distinguishing fact in that case was that the university did not use a statutory disciplinary power, but rather acted following notice from the University of Victoria Student Society (UVSS) that the pro-life group and its displays contravened the UVSS Clubs Policy, including policies regarding discrimination and harassment. ${ }^{234}$ The university was found to have exercised power "within the University's sphere of autonomous operational decision-making." ${ }^{235}$ An Alberta case examined the University of Alberta's decision to charge a substantial security fee to a pro-life group seeking permission to hold an event on campus. The Court found the decision reasonable without ruling on whether the Charter applied. ${ }^{236}$ Where the Charter does apply, campus expression cases provide an opportunity to assert section 15 of the Charter to buttress harassment policies, codes of conduct, or disciplinary policies that promote equality and

Ismail, supra note 15 at para 340.

Charter, supra note $1, \mathrm{~s} 15$.

McKinney, supra note 68; Harrison v University of British Columbia, [1990] 3 SCR 451.

See e.g. Blaber $v$ University of Victoria (1995), 123 DLR (4th) 255 (BCSC); Tefler $v$ University of Western Ontario, 2012 ONSC 1287; AlGhaithy v University of Ottawa, 2012 ONSC 142.

2010 ABQB 644, [Pridgen ABQB], aff'd 2012 ABCA 139 [Pridgen ABCA].

SA 2003, c P-19.5 [PSLA].

Pridgen ABQB, supra note 228 at para 81.

Though the section 15 issue may not have been pressed on appeal, as the Court of Appeal noted that Doré did not alter its analysis and dismissed the university's appeal (Pridgen ABCA, supra note 228 at paras 176-77). 2014 ABQB 190.

2015 BCSC 39, aff'd 2016 BCCA 162, leave to appeal to SCC refused, 37094 (1 December 2016). Ibid at paras $148-52$.

Ibid at para 149.

UAlberta Pro-Life v Governors of the University of Alberta, 2017 ABQB 610. 
censure discrimination or harassment. Pro-life displays were considered contrary to the UVSS's harassment policy, and abortion rights are considered by many to be an equality issue, as well as engaging section 7 rights. ${ }^{237}$ Disciplinary action against other forms of speech on campus that violate codes of conduct could equally be buttressed by a Charter values argument under the $D / L$ framework.

In Taylor-Baptiste, the applicant, joined by the Ontario Human Rights Commission, argued that Charter equality rights weighed in favour of finding online postings by union employees about a member of management to be discriminatory. ${ }^{238}$ The Commission took the position, on argument for reconsideration, that the Tribunal's decision was contrary to Commission policies regarding "inappropriate gender-related behavior" toward women in authority. ${ }^{239}$ The Tribunal held that the employees' statements were outside the workplace and therefore not within the Tribunal's jurisdiction, and were in any case protected by sections 2(b) and 2(d) of the Charter. The decision was upheld on appeal. ${ }^{240}$ Deploying Charter rights in support of state action against individuals via the mechanisms of human rights legislation is therefore no guarantee of success. Not every tribunal will automatically see the $D / L$ framework as a licence to "weigh thy words in a balance, and make a door and bar for thy mouth." ${ }^{241}$ Ismail and Whatcott, however, establish precedents for invoking the Charter in favour of state action against individuals. The legislation ${ }^{242}$ that was accepted by the Supreme Court in Whatcott as doing the work of equality rights in the Charter, provides a tool by which the state $^{243}$ or an individual ${ }^{244}$ may initiate a complaint, the state may investigate $^{245}$ and carry out search and seizure ${ }^{246}$ against an individual, require parties to enter into mediation, ${ }^{247}$ apply to a court to require attendance at a hearing, and order various remedies against an individual following a hearing. ${ }^{248}$ As long as there is a plausible appeal to be made to a Charter value, there is no obstacle in principle to the Charter being invoked via $D / L$ balancing to provide remedies against individuals at any administrative tribunal or by any administrative decision-maker with the statutory power to affect private persons.

See e.g. Joanna N Erdman, "A Constitutional Future for Abortion Rights in Canada" (2017) 54:3 Alta L Rev 727 at $744 \mathrm{ff}$. The Alberta Court of Appeal suggested it might have considered weighing sections 7 and 15 of the Charter in favour of upholding the decision of a transit authority to refuse advertisements from a pro-life group (had the argument been advanced) (Canadian Centre for BioEthical Reform v Grand Prairie (City), 2018 ABCA 154 at para 72, Slatter JA). Taylor-Baptiste Tribunal, supra note 18 at paras 6, 44-45.

Ibid at para 50.

See supra note 18.

The Holy Bible, King James Version (Cambridge, UK: Chadwyck-Dedley, 1996), Ecclesiasticus 28:25. Similarly, the Ontario Superior Court used the $D / L$ framework to declare that a decision of the Children's Aid Society of Hamilton to remove a child from a Christian foster family because the family might not sufficiently endorse the existence of the Easter Bunny failed to sufficiently accommodate the family's Charter-protected religious and expressive rights (Bv Children's Aid Society of Hamilton, 2018 ONSC 1487.

The Saskatchewan Human Rights Code, SS 1979, c S-24.1.

Ibid, s 27(3).

Ibid, s 27(1).

Ibid, s 28(1)(c).

Ibid, s 28.1.

Ibid, s 29.5(1).

Ibid, s 31.3(1), Part V. 


\section{New Positive Charter Rights}

The $D / L$ framework provides a medium through which to develop positive Charter claims in furtherance of social causes that might be advanced through various types of administrative boards and tribunals. As discussed above, the Charter has historically provided few free-standing positive entitlements other than language rights. Movement toward more robust Charter-based entitlements has been seen in administrative decisions in labour and human rights law. Brandt Tractor demonstrates how the derivative positive rights to collective bargaining upheld in BC Health Services and Dunmore can be effectively asserted through the $D / L$ framework to keep members from decertifying. Ismail demonstrates how the Charter can assist in preventing unwanted speech. Before the $D / L$ framework, the legal means to prevent inappropriate speech were limited to positive legislation: human rights legislation and the Criminal Code. ${ }^{249}$ Through the $D / L$ framework, such legislation becomes a conduit by which Charter rights and values may be invoked to affect a decision. Where Charter values invigorate legislation, they may support various legislated positive entitlements.

In Ismail and Whatcott, Charter values were found to support a complainant's right to invoke the power of the state to limit discriminatory or hateful speech. ${ }^{250}$ The same position was advanced by the Ontario Human Rights Tribunal in Taylor-Baptiste. ${ }^{251}$ The understanding that the Charter supports positive anti-discrimination legislation is wellestablished within the commissions and tribunals that administer human rights legislation. This is evident, for example, in the following statement of the Chief Commissioner of the Canadian Human Rights Commission, speaking to Parliament about the Canadian Human Rights $A c t^{252}$ provisions on hate speech:

$[\mathrm{H}]$ ow do we balance two freedoms, if you will, or two rights? These two rights are the freedom of expression, which is a fundamental right for Canadians protected and guaranteed by the charter, and the freedom from discrimination, which is a fundamental right for Canadians protected in the charter and the Canadian Human Rights Act. ${ }^{253}$

It is also evident in this comment in a judgment from the British Columbia Human Rights Tribunal: "this case engages two competing and fundamentally important rights, one enshrined in the Charter and the other enshrined both in the Charter and in the Code." ${ }^{254}$ Or this statement from the Ontario Human Rights Commission concerning a human rights complaint about an article by Mark Steyn published in Maclean's magazine: "[t]he Maclean's article and others like it raise important human rights issues for the affected at 5 (Chair: Ed Fast), online: <www.ourcommons.ca/Content/Committee/402/JUST/Evidence/EV417 2980/JUSTEV43-E.PDF>.

Elmasry v Roger's Publishing Ltd (No 4), 2008 BCHRT 378 at para 28. 
communities and those who are concerned with the balance between freedom of expression and equality rights." 255

The rights in human rights legislation provide protections, but they are protections from individuals and private entities as well as from the state. They provide the means to assert positive rights: the right to make a complaint and to request an investigation, and, in appropriate circumstances, the right to a hearing and an award in compensation for discrimination, possibly in conjunction with an order restraining the respondent's speech in some way. ${ }^{256}$ Such rights imply corresponding duties on individuals (as well as the state) not to act in certain ways. Rather than merely being restrictions on the state, they include entitlements distributed $b y$ the state to victims of discrimination. Human rights legislation has been held to be "fundamental law," deserve a "liberal and purposive" interpretation. ${ }^{258}$ Some provincial human rights legislation states that it is "paramount," 259 will "prevail," 260 or has "primacy" 261 over other laws of the jurisdiction. Human rights laws are, nonetheless, a form of governmental action: there is a categorial difference between such legislation and constitutional restraints. Human rights commissions and tribunals, like many other boards, commissions, and tribunals governing workers' compensation, social services, housing, and so on, administer policy implemented through a "rights statute," 262 which creates "the rights, privileges, and corresponding obligations needed to effectuate that policy." 263 In the statutory human rights context, positive anti-discrimination legislation is naturally considered commensurate with Charter rights, as is evidenced, for example, by the following statement in a letter by the Ontario Human Rights Commission to Maclean's magazine: "We need to keep in mind that freedom of expression is not the only right in the Charter. There is a full set of rights accorded to all members of our society, including freedom from discrimination. No single right is any more or less important than another."264

For many purposes there will be little functional difference - for a human rights commission or tribunal exercising statutory discretion - between Charter-based freedoms and positive rights in legislation supported by Charter values. In this context, it is clear how human rights lawyer Pearl Eliadis could describe the Supreme Court's decision in Taylor as upholding the "unconstitutionality of hate speech." 265 On the orthodox understanding of the

Ontario Human Rights Commission, "Commission Statement Concerning Issues Raised by Complaints Against Maclean's Magazine” (9 April 2008), online: <www.ohrc.on.ca/en/news_centre/commissionstatement-concerning-issues-raised-complaints-against-macleans-magazine $>$.

See e.g. Canadian Human Rights Act, RSC 1985, c H-6, ss 40, 43, 50, 53; The Saskatchewan Human Rights Code, SS 1979, c S-42.1, ss 27-28, 29.6, 31.3; Human Rights Code, RSO 1990, c H.19, ss 31, 33-34, 44, 45.2, 53.

Insurance Corp of BC v Heerspink, [1982] 2 SCR 145 at 158.

$B v$ Ontario (Human Rights Commission), 2002 SCC 66 at para 44.

The Human Rights Code, CCSM, c H-175, Preamble, s 58.

Human Rights Code, RSBC 1996, c 210, s 4; Human Rights Code, RSO 1990, c H.19, s 47(2) [Ont Human Rights Code]; Human Rights Act, RSPEI 1988, c H-12, s 2(2); Charter of Human Rights and Freedoms, CQLR c C-12, s 52. Ont Human Rights Code, ibid.

Ron Ellis, Unjust by Design: Canada's Administrative Justice System (Vancouver: UBC Press, 2013) at 135 .

Ibid.

Barbara Hall, Chief Commissioner of the Ontario Human Rights Commission, Letter to the Editor, Maclean's (22 April 2008), online: <www.ontla.on.ca/ library/repository/mon/22000/281522.pdf>.

Pearl Eliadis, Speaking Out on Human Rights: Debating Canada's Human Rights System (Montreal: McGill-Queen's University Press, 2014) at 220, discussing Taylor, supra note 171. 
Charter, Taylor found the hate speech legislation to be constitutional; private speech cannot be constitutional or unconstitutional. As Charter values and rights have been found to infuse the positive legislation, however, it has become meaningful to say that hate speech is unconstitutional (insofar as it violates human rights legislation which instantiates Charter rights and values).

Charter-based entitlements to prevent discriminatory speech are well established in human rights law, just as the Charter basis for a right to keep someone within a union or bargaining group has been established in labour law. The use of Charter values to leverage positive rights via $D / L$ balancing has a broad potential application. In Thelwell, $D / L$ balancing was invoked to review a decision of the Investigations Division of the Passport Integrity Branch of Citizenship and Immigration Canada not to issue a passport because false information had been provided on the passport application. ${ }^{266}$ In this case the effect of applying the $D / L$ framework could be seen as either leveraging an entitlement (such as an entitlement to a passport) or restraining the extent to which an administrative decision-maker may restrict Charter-protected mobility rights. Similarly, the use of the $D / L$ framework to review a decision to withhold benefits from a claimant who had refused to also apply for CPP benefits in Stadler ${ }^{267}$ could reasonably be seen as an attempt to expand an entitlement or a use of the equality right as a restraint. Nonetheless, these cases show the potential for new avenues for Charter advocacy, from which further positive entitlements may develop.

As administrative decision-makers apply $D / L$ to allow or disallow statutory entitlements, the distinction between use of the Charter as a restraint and use of the Charter to support a positive entitlement may prove difficult to maintain in some cases. The Federal Court's decision in Thelwell is, on its face, a finding that section 6 Charter restraints were not properly considered by the Investigations Division. Whether there is some degree of positive entitlement flowing from section 6 that is logically implied by this is not necessarily a question that tests any important assumptions of constitutional or administrative law. Other cases may raise more significant issues, however. In Gosselin, the Supreme Court acknowledged the possibility that the facts in some cases might support a section 7 argument for positive entitlements, including economic entitlements. ${ }^{268}$ What if a tribunal were to weigh section 7 , in the course of exercising its discretion, on the side of an entitlement to social assistance? The distinction between weighing Charter values in the course of exercising discretion and conferring a benefit by identifying a positive Charter entitlement would be hard to maintain in such a case.

Any finding of a significant Charter entitlement by a decision-maker applying the $D / L$ framework also raises an issue as to jurisdiction and the appropriate standard of review. The central question addressed by the Supreme Court in Doré was whether "Charter guarantees and the values they reflect" could be adequately protected through the exercise of discretion that would attract deference on review. ${ }^{269}$ The majority expressed confidence that " $[\mathrm{t}] \mathrm{he}$ notion of deference in administrative law should no more be a barrier to effective Charter 
protection than the margin of appreciation is when we apply a full s. 1 analysis." ${ }^{270}$ If Ismail and Brandt Tractor have not disturbed this confidence, there may yet arise cases that do. Some tribunals are statutorily precluded from deciding issues of constitutionality. For example, the Ontario Works Act, 1997, which establishes the Ontario Social Benefits Tribunal, provides at section 67(2)(a) that the "Tribunal shall not inquire into or make a decision concerning, the constitutional validity of a provision of an Act or a regulation."271 The British Columbia Administrative Tribunals Act states at section 45 that any tribunal to which the Act applies "does not have jurisdiction over constitutional questions relating to the Canadian Charter of Rights and Freedoms., ${ }^{272}$ The Court in Ismail noted this, ${ }^{273}$ but held that Doré nonetheless obliged the BC Human Rights Tribunal to consider Charter values in its exercise of discretion ${ }^{274}$ (and that the statutory objective of eliminating discrimination is grounded in the Charter value of equality ${ }^{275}$ ). Similarly, in Duncan v. Retail Wholesale Union Pension Plan, the Court, on reviewing a decision of the British Columbia Human Rights Tribunal as to whether the provisions of a private pension plan discriminated against unmarried employees, noted section 45 of the $A T A$, but held nonetheless (citing Doré, Loyola, and Ismail), on a correctness standard, that the tribunal's failure to consider Charter values was an error of law. ${ }^{276}$ In United Food and Commercial Workers, Local 401 v Alberta (Attorney General), ${ }^{277}$ the Alberta Court of Appeal addressed a situation in which an Adjudicator appointed by the Alberta Information and Privacy Commissioner held that a union's videotaping of persons crossing a picket line was not authorized by the Personal Information Protection Act. ${ }^{278}$ The Court noted that the Privacy Commissioner and his Adjudicators had no jurisdiction, by virtue of the Alberta Administrative Procedures and Jurisdiction Act, ${ }^{279}$ to determine a question of constitutional law. ${ }^{280}$ In considering the potential scope of the Adjudicator's discretionary application of Charter values to the competing privacy, freedom of association, and freedom of expression interests under Doré, the Court noted that:

[B]ecause the statute limits their power to directly resolve Charter issues by limiting their jurisdiction, the statute will necessarily influence the standard of review analysis relating to the tribunal's decisions. As Doré points out at para. 30, the rule in Dunsmuir is based in part on legislative intent, and the intent of the Administrative Procedures and Jurisdiction Act is clearly that the excluded tribunals have a limited role to play in this area.

The decision in Doré was premised at paras. 29, 35 [sic] on a tribunal "both bound by fundamental values and empowered to adjudicate them, and that administrative discretion is exercised in light of institutional guarantees and the values they reflect". That important presumption does not prevail in Alberta, where the

Ibid at para 5 .

SO 1997, c 25, Schedule A, s 67(2)(a).

SBC 2004, c 45, s $45[A T A]$.

Ismail, supra note 15 at para 304.

Ibid at paras 306-10.

Ibid at paras 325,340 .

2017 BCSC 2375 at paras 58, 64, 83-86, 90-95, 108.

2012 ABCA 130 [UFCW], aff'd 2013 SCC 62.

SA 2003, c P-6.5 [PIPA].

RSA 2000, c A-3, s 11.

UFCW, supra note 277 at paras 41,78 . 
Legislature has recognized that many tribunals do not have the internal expertise to decide constitutional issues. $^{281}$

The Court of Appeal found the application of PIPA to the union's activities to be unconstitutional. ${ }^{282}$ The decision was upheld by the Supreme Court, ${ }^{283}$ without comment on the standard of review issue. The Dunsmuir presumption of a standard of review of reasonableness has been rebutted in some cases on the basis of legislative intent as reflected in a tribunal's statutory scheme. ${ }^{284}$ There is some inconsistency in the way the courts have approached this issue: if the exercise of administrative discretion creates further significant novelty in the way the Charter is applied (for instance, by invoking section 7 to provide a benefit), the standard of review in such cases might be revisited, perhaps to require greater scrutiny in those cases where Charter values are weighed on the side of state action. ${ }^{285}$ The rule of law requires that legal rights and liabilities are resolved by application of the law rather than through the exercise of discretion. ${ }^{286}$ The issue is made more pressing where the rights and liabilities involved are those that flow from our ultimate law (that is, the constitution, including the Charter). In its Trinity Western decisions, the Supreme Court went some distance toward imposing a correctness standard on review of decisions that use the $D / L$ framework. The Supreme Court held that though the standard remains reasonableness, "[s]imply put, a decision that has a disproportionate impact on Charter rights is not reasonable." 287 The Court might go further, and stipulate that any administrative decision that applied a Charter right to support state action should be considered a "matter of central importance to the legal system and outside the ... area of expertise of the decisionmaker" for the purposes of Dunsmuir ${ }^{288}$ (and therefore reviewable on a correctness standard). If there is any tightening of the standard of review regarding the application of Charter values in the exercise of administrative discretion, however, human rights tribunals may be insulated from it, as the Supreme Court has, in numerous cases, acknowledged a broad scope for the specialized expertise of such tribunals in their determination of rights issues. ${ }^{289}$

Ibid at paras 42-43.

Ibid at para 82 .

Supra note 277.

See e.g. Tervita Corp v Canada (Commissioner of Competition), 2015 SCC 3 at paras 34-39; SODRAC, supra note 156 (further, different standards of review may be applied to different aspects of a decision). See Daly, "Reasonableness Review," supra note 163.

See AV Dicey, Introduction to the Study of the Law of the Constitution (Indianapolis: Liberty Fund, 1982) at 255-60; Tom Bingham, The Rule of Law (London: Allen Lane, 2010) at 48-54.

$T W v$ LSBC SCC, supra note 21 at para 80. See also Chief Justice McLachlin's concurring opinion at paras 107-51; TW v LSUC SCC, supra note 21 at para 35.

Supra note 156 at para 55.

See e.g.Whatcott, supra note 16 at paras 166-68; Mouvement lä̈que québécois, supra note 156 though note that the Supreme Court did apply the standard of correctness to the question of "benevolent neutrality" (ibid at para 49); Quebec (Commission des normes, de l'équité, de la santé et de la sécurité $d u$ travail) $v$ Caron, 2018 SCC 3 . The statutory framework of some human rights tribunals also encourages deference: for instance, section 45.8 of the Ont Human Rights Code, supra note 260 contains a privative clause that allows review only where a decision of a tribunal is patently unreasonable. Though the courts on review have abandoned that standard, the privative clause still supports a reasonableness standard of review: see Abbey v Ontario (Community and Social Services), 2018 ONSC 1899 at para 22 . 


\section{CONSTitutionalism AS AN Underlying Principle of The Charter}

Administrative law may be moving away from an orthodox conception of the Charter through application of the $D / L$ framework. It is not clear that this potential evolution is restrained in any way by existing jurisprudence on the Charter's role within any normative conception of constitutionalism. The Supreme Court has acknowledged that there is an "internal architecture" 290 or "basic constitutional structure" 291 to the constitution, including the Charter. ${ }^{292}$ The Supreme Court has also listed "constitutionalism and the rule of law"293 as among the "underlying principles"294 that make up that structure as "vital unstated assumptions" "295 that "inform and sustain the constitutional text." 296 This might be taken to entail restraints on government and to preclude intrusion, via a charter of rights, into private relations, given the common understanding of the term "constitutionalism":

[I]n all its successive phases, constitutionalism has one essential quality: it is a legal limitation on government; it is the antithesis of arbitrary rule; its opposite is despotic government, the government of will instead of law. ${ }^{297}$

Constitutionalism is the idea, often associated with the political theories of John Locke and the founders of the American republic, that government can and should be legally limited in its powers, and that its authority or legitimacy depends on its observing these limitations. ${ }^{298}$

[I]n the broadest terms, modern constitutionalism requires imposing limits on the powers of government, adherence to the rule of law, and the protection of fundamental rights. ${ }^{299}$

The Supreme Court's exposition of how the concept of constitutionalism structures a bill of rights, however, is thin, and at points contradictory. The Supreme Court's most detailed comments are in the Secession Reference. ${ }^{300}$ There, the Supreme Court describes constitutionalism as including the recognition that the people have the capacity to commit to being bound by constitutional rules in the future, ${ }^{301}$ and requiring that "all government action comply with the Constitution." 302 The Supreme Court did not state that providing a restraint on the state to protect individual freedom is necessary and internal to the concept

Reference re Secession of Quebec, [1998] 2 SCR 217 at para 50 [Secession Reference]. OPSEU v Ontario (Attorney General), [1987] 2 SCR 2 at 57; Reference re Senate Reform, 2014 SCC 32 at para 26; Secession Reference, ibid at para 50.

Gosselin, supra note 92 at para 285, Arbour J, dissenting.

Secession Reference, supra note 290 at paras $70-78$.

Ibid at para 49.

Ibid.

Ibid.

Charles Howard McIlwain, Constitutionalism: Ancient and Modern, revised ed (Ithaca, New York: Great Seal Books, 1947) at 21-22.

Wil Waluchow, "Constitutionalism" in Edward N Zalta et al, eds, The Stanford Encyclopedia of Philosophy (Spring 2018 edition), online: <https://plato.stanford.edu/entries/constitutionalism> .

Michel Rosenfeld, "Modern Constitutionalism as Interplay Between Identity and Diversity" in Michel Rosenfeld, ed, Constitutionalism, Identity, Difference, and Legitimacy: Theoretical Perspectives (Durham: Duke University Press, 1994) 3 at 3.

Supra note 290.

Ibid at para 76.

Ibid at para 72 . 
of constitutionalism in our legal system. ${ }^{303}$ The majority noted only that "a constitution may provide an added safeguard for fundamental human rights and individual freedoms." 304 Providing restraints on the state to protect fundamental freedoms appears, in the Secession Reference, to be considered only accidental to our modern constitution. While the proposition that the aim of a bill of rights is to restrain the state has a great amount of support elsewhere in our Charter jurisprudence, its stronger classical liberal formulation - that the role of a bill of rights is only to restrain the state - does not. ${ }^{305}$ Justice Arbour argued in her dissent in Gosselin that positive action was not only consistent with the structure of section 7 of the Charter, but compelled by it. ${ }^{306}$ This argument was not rejected in theory by the majority, which found no positive action required on the facts in that case, but invoked Lord Sankey's "living tree" metaphor, and acknowledged that "[o]ne day s.7 may be interpreted to include positive obligations." 307

The idea of embracing "post-liberal constitutionalism," honouring the notion that "human freedom is often advanced, not curtailed, by positive action of the state" ${ }^{308}$ has met with some resistance, ${ }^{309}$ but has been embraced by others. ${ }^{310}$ James Tully, for instance, warns of accepting the assumptions of orthodox liberalism, which import into our ideas of justice "a number of unexamined conventions, inherited from the imperial age, that continue to inform the language of constitutionalism."311 Differing conceptions of constitutionalism have been cited as marking a historical cultural divide within Canada. ${ }^{312}$ The nature of constitutionalism is a point of disagreement in McKinney, where Justice Wilson, writing in dissent, describes

For the purposes of the Secession Reference, ibid, the Supreme Court was most concerned with weighing the binding effect of the principle of constitutionalism against other fundamental values, so as not to preclude negotiation: see Webber, supra note 53 at 261. The liberal dimension of constitutionalism was not the most relevant aspect of the principle to the question being decided.

Secession Reference, ibid at para 74 [emphasis added].

The classical liberal position was expressed in the dissent by Justices Côté and Brown in TWvLSUC SCC, supra note 21 (" $[\mathrm{t}] \mathrm{he}$ Charter binds state actors, like the LSUC, and only state actors. It does not bind private institutions, like TWU" at para 79 [emphasis in original]).

Supra note 92 at para 350.

Ibid at para 82.

Thomas MJ Bateman, "Rights Application Doctrine and the Clash of Constitutionalisms in Canada," (1998) 31:1 Can J Political Science 3 at 6.

See ibid; Bateman, "Liberal Versus Post-Liberal Constitutionalism," supra note 98 at 29.

See e.g. Yves de Montigny, "Section 32 and Equality Rights" in Anne F Bayefsky \& Mary Eberts, eds, Equality Rights and the Canadian Charter of Rights and Freedoms (Toronto: Carswell, 1985) 565; James Tully, Strange Multiplicity: Constitutionalism in an Age of Diversity (Cambridge: Cambridge University Press, 1995); Gavin W Anderson, "Understanding Constitutional Speech: Two Theories of Expression" in Gavin W Anderson, ed, Law in its Social Setting: Rights and Democracy: Essays in UKCanadian Constitutionalism (London: Blackstone Press, 1999) 49 (advocating a "pluralist liberalism" over a classical liberal approach to constitutional protections); Duncan Ivison, "Constitutional Unity and Complex Identification" (2000) 25:2 Australian J Leg Philosphy 225; Patricia Hughes, "Recognizing Substantive Equality as a Foundational Constitutional Principle"(1999) 22:2 Dal LJ 5 (Hughes does not take a position that she characterizes as post-liberal, but does advocate a form of substantive equality which includes a variety of forms of mutual recognition, which she notes is viewed by some as a defining element of post-liberal constitutionalism); Dave Snow, "The Judicialization of Assisted Reproductive Technology Policy in Canada: Decentralization, Medicalization, and Mandatory Regulation" (2012) 27:2 Can JL \& Soc 169.

Tully, ibid at 34 .

Katherine Swinton "Competing Visions of Constitutionalism: Of Federalism and Rights" in Katherine E Swinton \& Carol J Rogerson, eds, Competing Constitutional Visions: The Meech Lake Accord (Toronto: Carswell, 1988) 279 (the entrenchment of the Charter is described as a development within a turn after the Second World War away from preoccupation with division of powers and federalism toward "a competing vision of Canadian constitutionalism, not territorially based.... Rights consciousness led to pressure from interest groups and citizens for constitutional guarantees of individual rights against government, and statutory safeguards against discrimination both public and private," at 281). 
the majority's constitutionalism as a doctrine by which "states are a necessary evil," 313 and describes constitutionalism as an American doctrine arising from that country's history, not shared by Canada. ${ }^{314}$ Canadian constitutionalism has been described by one academic as "a compilation of contending stories and counter-narratives." ${ }^{315}$ Another has described it "not as an ordered, structured and comprehensive body of rules, but as a body of experience" 316 which "might be called agonistic constitutionalism, for it acknowledges that parties often do disagree over fundamentals." 317

While the "internal architecture" of the constitution may not include a prescriptive understanding of constitutionalism that confines the concept of a bill of rights to something that restrains rather than empowers the state, there must nonetheless be a structure to at least some of the rights in the Charter that precludes some interpretations. As Thomas Paine wrote, constitutions are "to liberty, what a grammar is to language." 318 Without some grammar and consistency, language and law become nonsense. From contradiction, anything follows. Requiring workers to remain in a union during a labour dispute in furtherance of their freedom of association ${ }^{319}$ is arguably a contradiction. Using the Charter to buttress state enforcement of equality ${ }^{320}$ even while the Charter is said not to impose a positive obligation to counteract inequality ${ }^{321}$ may also seem to be a contradiction. To support is not to impose, but where the Charter tips the balance in favour of state action, the distinction becomes a delicate one.

Is there anything essential to the structure or grammar of the Charter that resists novel expressions of its protections as positive obligations? Brian Langille and Benjamin Oliphant have critically analyzed the law of derivative rights by means of a persuasive description of the "legal grammar" of freedom of association. ${ }^{322}$ While they admit the viability of "facilitative" constitutional rights, they suggest that legal coherence demands that they exist only where exercise of a freedom would otherwise be rendered impossible. ${ }^{323}$ Nonetheless, derivative positive labour rights continue to develop in novel ways. If there is a grammar of our Charter that governs its use the same way grammar governs the use of a language, it is considered to be a permissive one in current jurisprudence. If it might be accepted that the Charter's framers generally held an orthodox view of constitutionalism, this need not constrain interpretation either: the framers' intent was explicitly rejected as a limiting interpretive principle for the Charter by the Supreme Court in the Motor Vehicle Reference case. ${ }^{324}$ Some aspects of the Charter were deliberately left by the framers to be further

McKinney, supra note 68 at 342.

Ibid at 343-57.

Kate Glover, “The Supreme Court in Canada's Constitutional Order” (2016) 21:1 Rev Const Stud 143 at 164 .

Webber, supra note 53 at 260.

Ibid at 263.

Thomas Paine, The Rights of Man in Thomas Paine: Collected Writings (New York: Library of America, 1955 , orig pub 1775-76) 431 at 492.

Brandt Tractor, supra note 19.

Whatcott, supra note 16 at paras 47, 66, 145, 161; Ismail, supra note 15 at paras 185, 200, 211, 325, 340. Auton, supra note 144.

Langille \& Oliphant, "Legal Structure," supra note 99. See also Langille, "The Condescending Constitution," supra note 99.

Langille \& Oliphant, "Legal Structure," ibid at 289-93.

Motor Vehicle Reference, supra note 52 at 508-509. Some scholars have recently revisited the place of originalism in Canadian constitutional jurisprudence: Benjamin Oliphant \& Léonid Sirota, "Has the Supreme Court of Canada Rejected 'Originalism'?” (2016) 42:1 Queen's LJ 107; J Gareth Morley, "Dead Hands, Living Trees, Historic Compromises: The Senate Reform and Supreme Court Act References Bring the Originalism Debate to Canada" (2016) 53:3 Osgoode Hall LJ 745. 
specified by the courts. ${ }^{325}$ While "history assists in understanding the past, it need not necessarily command the future." ${ }^{326}$ As J. Gareth Morley has observed, the idea that there is a normative or "true meaning of the Constitution," requires an external standard of meaning that the "living tree" conception of the constitution cannot deliver. ${ }^{327}$ It has been argued that it then follows that Canadian constitutionalism is paradoxical and incoherent. ${ }^{328}$ Though this may overstate the case, Canadian constitutionalism is certainly contested. Arguing from the fundamental structure or logical grammar of the Charter can only resolve confusion where there is agreement about that structure. Where the fundamental concepts are indeterminate, or there is genuine theoretical disagreement, appeal to the logic or structure of the Charter will not assist. ${ }^{329}$

The lack of conceptual determinacy and agreement is magnified when one looks beyond the Supreme Court Charter jurisprudence to the views expressed by administrative bodies. Consider the contrast between this statement from a majority decision by the Supreme Court, "Charter rights are not a matter of privilege or merit, but a function of membership in the Canadian polity that cannot be lightly cast aside," 330 and this statement by the Ontario Human Rights Commission:

It is often said that with rights come responsibilities. It is the Commission's view that the media has a responsibility to engage in fair and unbiased journalism.... Freedom of expression should be exercised through responsible reporting.... In Canada, the right to freedom of expression is not absolute, nor should it be. ${ }^{331}$

The first statement expresses an orthodox constitutionalism. The second suggests that a legal protection implies a corresponding duty on the person who is protected, and that the Charter should not protect the irresponsible. The fact that this is not consistent with classical liberal

For example, when asked during parliamentary hearings on the constitution whether sexual orientation would count as an improper ground for discrimination, Jean Chrétien replied that "[i]t might. That would be for the court to decide, it is open ended" (Proceedings of SJC, supra note 44, Issue 39 (16 January 1981 ) at 17). See also Issue 36 (12 January 1981) ("the clause is open" at 32), Issue 48 (29 January 1981 ) ("other grounds of discrimination will be defined by the courts" at 33), and Issue 49 (30 January 1981) ("the courts interpret the right" at 29). Of course, this observation does not itself negate the relevance of evidence of framers' intent on issues of interpretation or application of the Charter; on the contrary, to cite evidence for lack of specific intent in some areas is to admit the relevance of similar evidence on other matters of interpretation.

NS, supra note 174 at para 92. The Federal Court of Appeal notes the evergreen nature of constitutional law in Schmidt v Canada (AG), 2018 FCA 55 at paras 91-97.

Morley, supra note 324 at 768. See also Kent Roach, The Supreme Court on Trial: Judicial Activism or Democratic Dialogue (Toronto: Irwin Law, 2001), ch 12.

Luc B Tremblay, "Marbury v. Madison and Canadian Constitutionalism: Rhetoric and Practice" (2004) 36:3 Geo Wash Intl L Rev 515 at 531ff.

On the limitations of argument from logical grammar, see GP Baker \& PMS Hacker, Wittgenstein: Rules, Grammar, and Necessity, vol 2 (Oxford: Wiley Blackwell, 2014) at 55-59. Cf Isaiah Berlin, "Does Political Theory Still Exist?" in Isaiah Berlin, Concepts and Categories: Philosophical Essays (London: Hogarth Press, 1978) 143 at 149:

Indeed, it seems clear that disagreements about the analysis of value concepts, as often as not, spring from profounder differences, since the notions of, say, rights or justice or liberty will be radically dissimilar for theists and atheists, mechanistic determinists and Christians, Hegelians and empiricists, romantic irrationalists and Marxists, and so forth. It seems no less clear that these differences are not, at least prima facie, either logical or empirical, and have usually and rightly been classified as irreducibly philosophical.

Sauvé v Canada (Chief Electoral Officer), 2002 SCC 68 at para 14.

Ontario Human Rights Commission, supra note 255. 
constitutionalism and disrupts the legal relations described by Wesley Hohfeld ${ }^{332}$ is unlikely to change the Commission's position on the matter. This is a case of genuine theoretical disagreement $^{333}$ (as well as reflecting the Commission's policy, developed on the basis of a statutory mandate) that an appeal to orthodoxy will not resolve.

The progress of the $D / L$ framework has nonetheless been seen by some as inconsistent with the Charter's constitutional role. Justices Lauwers and Miller find the $D / L$ procedure of identifying and balancing Charter values to be "irremediably subjective" and "ad hoc" because "there is no doctrinal structure to guide their identification or application." ${ }^{334}$ In ET $v$ Hamilton-Wentworth, ${ }^{335}$ Justice Lauwers expresses reservations about the extension in Loyola of the Doré framework to "a discretionary decision that is not adjudicated," 336 where identifying a statutory objective with a Charter value can be "a rhetorical move - a resultselective conclusion — and not the outcome of a transparent analytical process. ${ }^{\prime 337} \mathrm{He}$ is also critical of the $D / L$ analysis as formulated in Loyola, whereby a decision-maker is asked to "balance the Charter protections to ensure that they are limited no more than is necessary given the applicable statutory objectives." 338 Justice Lauwers' concern is that this formulation appears to reverse the burden of establishing Charter compliance: whereas in Oakes, Charter rights have "defeasible priority" over statutory aims, ${ }^{339}$ in the Loyola formulation of the proportionality analysis, the reverse appears to be true. ${ }^{340}$

The potential of the $D / L$ mechanism to generate novelties in the application of Charter rights is magnified whenever the scope of Charter rights is widened. Any criticism of widening of the scope of a Charter right that draws on an orthodox conception of constitutionalism (criticism of an innovative fulcrum) will apply a fortiori to the potential application of the expanded interpretation within the $D / L$ framework (use of the lever). For instance, Justice Rothstein, in his reasons concurring in the result in Fraser and in his dissent in Mounted Police Association, was highly critical of the uses to which "freedom of association" was put (following BC Health Services). In Fraser he objected to, among other things, assigning collective dimensions to an individual right, assigning positive obligations to freedom of association, and privileging certain associations over others. ${ }^{341} \mathrm{He}$ wrote that in his view,

it is clear that s. $2(d)$ is intended to protect a sphere of individual autonomy or liberty, and not to enhance by state action the capacity of individuals to do a particular activity more effectively or to guarantee that any particular endeavour for which association might take place will succeed. ${ }^{342}$

Wesley Newcomb Hohfeld, Fundamental Legal Conceptions as Applied in Judicial Reasoning and Other Legal Essays (New Haven: Yale University Press, 1919).

The Supreme Court did recognize a defence of responsible communication on matters of public interest in Grant v Torstar Corp, 2009 SCC 61, though as a defence to a private libel action, and not as a condition of constitutional protection.

Gehl, supra note 24 at paras 79-80.

Supra note 25.

Ibid at para 109 .

Ibid at para 104.

Ibid at para 111, citing Loyola, supra note 9 at para 4.

$R v$ Oakes, [1986] 1 SCR 103 at 108.

ET v Hamilton-Wentworth, supra note 25 at paras 108-17.

Fraser, supra note 109 at paras 177-215, Rothstein J, dissenting.

Ibid at para 202. 
In Mounted Police Association, he objected to what he saw as judicial usurpation of a legislative role ${ }^{343}$ with an effect that would "effectively compel a single model of collective bargaining." 344 He argued that constitutionalizing a Wagner model of labour relations would entrench a "majoritarian exclusivity" 345 in which many employees could see their freedom of association constrained rather than protected. Employees within a minority in the workplace would not be protected: on the contrary, section 2(d) rights would be interpreted to constrain their choice of association. ${ }^{346}$ Elsewhere he has criticized the idea that freedom of association "imposes obligations on others to facilitate associative objectives." ${ }^{347}$ Where such criticisms have any merit, they will apply with stronger reason to the implementation of the expansive interpretation via the $D / L$ framework, simply because the framework allows greater discretion and is reviewable on a reasonableness basis. ${ }^{348} \mathrm{~A}$ decision-maker drawing on section 2(d) Charter rights and values may choose to emphasize protection of freedom to choose with whom one will associate - including freedom not to associate — or (as in Brandt Tractor) promoting the majoritarian principle that favours collective bargaining, the expedited settlement of disputes, and industrial stability. The wider the scope of discretion, the less predictability, the less assurance that freedoms will always be protected, the more danger of a perception that decisions may be arbitrary or that lip service to "Charter values" serves some other agenda.

The Supreme Court, in its Trinity Western decisions, has acknowledged the scope of discretion available within the $D / L$ framework, and clarified the standard of review accordingly. While the standard of review remains reasonableness, preserving deference to administrative decision-makers when they are acting within their area of expertise, the Court has stipulated that "a decision that has a disproportionate impact on Charter rights is not reasonable." 349 It will therefore be open to a reviewing court to find an exercise of administrative discretion that engages Charter rights through the $D / L$ framework not to be correctly proportionate, and to be, therefore, unreasonable. The majority, however, reaffirmed that the requirement of the decision-maker is that he or she "gives effect, as fully as possible, to the Charter protections at stake given the particular statutory mandate. $" 350$ The majority did not address concerns regarding the onus of justification of a Charter breach, or affirm that Charter rights are presumed to have priority when balancing among Charter rights, Charter values, and statutory objectives. The Chief Justice, in a concurring judgment, gave weight to these concerns, asserting that the onus should always be on the state actor ${ }^{351}$ and that "it is the right itself ... that receives protection under the Charter." ${ }^{352}$ The Chief Justice also asserted that the interpretation of the scope of Charter rights should always be

Mounted Police Association, supra note 105 at paras 159-61, Rothstein J, dissenting.

Ibid at para 165 .

Ibid at para 183 .

Ibid.

Rothstein, supra note 99 at 12-13; see also Saskatchewan Federation of Labour, supra note 108 at para 125.

Dunsmuir, supra note 156 (for example, "the existence of justification, transparency and intelligibility within the decision-making process [and also with] whether the decision falls within a range of possible, acceptable outcomes which are defensible in respect of the facts and law" at para 47).

$T W v L S B C$ SCC, supra note 21 at para 80. See also McLachlin CJC, concurring at paras 118, 150; TW $v$ LSUC SCC, supra note 21 at para 35.

$T W v L S B C$ SCC, ibid at para 105, citing Loyola, supra note 9 at para 39.

$T W v L S B C$ SCC, ibid at para 117.

Ibid at para 115 . 
reviewable on a correctness standard. ${ }^{353}$ Adopting the Chief Justice's proposed clarifications of the $D / L$ framework would no doubt strengthen Charter protections and help to keep novel applications within the rule of law as the framework develops. Justice Rowe, concurring, ${ }^{354}$ and Justices Côté and Brown dissenting, ${ }^{355}$ more strongly endorsed many of the academic and judicial criticisms of the $D / L$ framework, most of which are captured sharply within Justices Côté and Brown's statement that "resorting to Charter values as a counterweight to constitutionalized and judicially defined Charter rights is a highly questionable practice."356

Many criticisms of the $D / L$ framework ${ }^{357}$ draw on an orthodox understanding of the Charter's essential role as a set of protections rather than a catalogue of values that imply a related "to do" list for the state. Associating a state aim with a Charter value for the purposes of a proportionality analysis may place a dispositive thumb on the scale. The effect may be seen as a form of Rousseauvian ${ }^{358}$ sleight of hand: the Charter still functions to protect freedoms, but it does so by encouraging action according to an agreed set of values. Where these values are invoked to give "Charter benediction" 359 to state action, rather than allowing the legitimacy of the goal to be established in its own right, the state enters the analysis with an advantage. The list of Charter values is not yet completely specified, and almost all legislation has a purpose that might be associated with a Charter value in some way. To criticize identifying a relevant Charter value in support of legislation as "a rhetorical

Ibid at para 116. See also ibid at paras 176-94, Rowe J.

Ibid at paras 162-207.

Ibid at paras 302-14; TW $v$ LSUC SCC, supra note 21 at para 75.

$T W v L S B C$ SCC, ibid at para 307.

See e.g. Hoi L Kong, "Doré, Proportionality and the Virtues of Judicial Craft" (2013) 63 SCLR (2d) 501 (criticizes, inter alia, the modified $D / L$ proportionality analysis in conjunction with deference); Alexander Pless, "Judicial Review and the Charter from Multani to Doré" (2014) 65 SCLR (2d) 293 ("Doré introduces a heterodox framework of mixed messages and inconstant guidance" at 322); Christopher D Bredt \& Ewa Krajewska, "Doré: All That Glitters is Not Gold” (2014) 67 SCLR (2d) 339 (especially the criticisms regarding the onus at 357-59); Macklin, supra note 163 (arguing that the Doré analysis devalues Charter rights, through the abridged proportionality analysis and the "structural asymmetry between deference in administrative law and deference in Charter analysis" at 579); Tom Hickman, "Adjudicating Constitutional Rights in Administrative Law" (2016) 66:1 UTLJ 121 ("[t]here is no escaping from the fact that the effect of Doré is to dissolve constitutional standards because the approach requires the application of a reasonableness standard which is less protective than a correctness standard, even when proportionality is in play" at 165); Paul Daly, "Prescribing Greater Protection for Rights: Administrative Law and Section 1 of the Canadian Charter of Rights and Freedoms" (2014) 65 SCLR (2d) 249 at 271-75; Janina Boughey, Human Rights and Judicial Review in Australia and Canada: The Newest Despotism? (Oxford: Hart Publishing, 2017) at 98-101; Peter D Lauwers, "Liberal Pluralism and the Challenge of Religious Diversity" (2017) 79 SCLR (2d) 29 at 56-58 [Lauwers, "Liberal Pluralism]; The Honourable Peter Lauwers, "Reflections on Charter Values: A Call for Judicial Humility" (12 January 2018), online: <www.ruleof law.ca/reflections-on-charter-values-a-call-forjudicial-humility/>. Evan Fox-Decent \& Alexander Pless, "The Charter and Administrative Law Part II: Substantive Review" in CM Flood \& L Sossin, eds, Administrative Law in Context, 3rd ed (Toronto: Emond Montgomery, 2018) 507 at 511-18; TW V LSBC SCC, supra note 21 at paras 115-17, McLachlin CJC, concurring, paras 162-208, Rowe J, concurring, paras 302-14, Côté and Brown JJ, dissenting; TW v LSUC SCC, supra note 21 at para 46, McLachlin CJC, concurring, paras 78-80, Côté and Brown JJ, dissenting; David Stratas "The Canadian Law of Judicial Review: A Plea for Doctrinal Coherence and Consistency" (17 February 2016), online: Social Science Research Network < https://ssrn.com/abstract= 2733751> "“[Doré] conflicts with earlier holdings based on the constitutional principle of legislative supremacy to the effect that the Charter does not add to or affect the subject-matter of subordinate bodies" at 5).

By this, I refer of course to Rousseau's doctrine that true freedom consists in the understanding of and submission to the general will, most famously expressed in the following passage: "whosoever refuses to obey the general will shall be constrained to do so by the entire body: which means nothing other than that he shall be forced to be free; for this is the condition which, by giving each Citizen to the Fatherland, guarantees him against all personal dependence" (Jean-Jacques Rousseau, Of the Social Contract in Victor Gourevitch, ed, Rousseau: The Social Contract and Other Later Political Writings (Cambridge: Cambridge University Press, 1997) 39 at 53).

The phrase was coined by Justice Abella in $R v$ Turcotte, 2005 SCC 50 at para 42. 
move," $" 360$ a "result-selective conclusion," $" 361$ or a "conclusory exercise" ${ }^{362}$ is to appeal to an orthodox constitutionalism that resists using Charter values to relax safeguards against interference with rights. The expansion of novel or progressive Charter claims within administrative law will test the extent of support for that orthodox understanding.

\section{CONCLuSion}

The framework for considering Charter interests established in Doré and Loyola creates various opportunities for advocacy and expansion of the types of uses to which the Charter might be put. As the $D / L$ framework has been developing, more expansive interpretations of certain Charter rights have been accepted within human rights and labour law. Positive rights of association have developed since Dunmore and $B C$ Health Services. These are beginning to be incorporated into more decisions through the $D / L$ framework. Brandt Tractor and Wsáneć School Board provide conspicuous examples of innovative effects on section 2(d) rights via the $D / L$ framework, whereby freedom of association is invoked to prevent people from ending their association with the union or bargaining group. In Keegstra, Justice McLachlin (as she was then), writing in dissent, objected to the use of section 15 to limit the scope of freedom of expression:

Given that the protection under s. $2(b)$ is aimed at protecting individuals from having their expression infringed by the government, it seems a misapplication of Charter values to thereby limit the scope of that individual guarantee with an argument based on s. 15, which is also aimed at circumscribing the power of the state. ${ }^{363}$

Section 15 was nonetheless used as the basis for asserting a Charter equality value which can counterbalance protection of freedom of expression, not only in Keegstra, but also in Zundel and Taylor. In Whatcott, the Supreme Court held that the equality right supports positive anti-discrimination legislation that limits speech. This conflicts with its recognition that freedom of expression promotes equality. Equality entails equal freedom. ${ }^{364}$ The Supreme Court has recognized autonomy as a value underlying freedom of expression. ${ }^{365}$ Control of an individual's expression involves inequality and subordination of that individual's autonomy. Frederick Schauer (who has been cited by the Supreme Court four times in freedom of expression cases) ${ }^{366}$ has described the relation between freedom of expression and equality in this way:

ET v Hamilton-Wentworth, supra note 25 at para 104.

Ibid; see also TW $v$ LSBC SCC, supra note 21 at paras 309-10, Côté and Brown JJ, dissenting.

$T W v L S B C$ SCC, ibid at para 193, Rowe J.

Supra note 70 at 833 .

Locke recognized that being equal includes being equally free: "[e]quality ... in respect of Jurisdiction or Dominion over one another ... being that equal right that every man has to his natural freedom, without being subjected to the will or authority of any other man" (Locke, The Second Treatise of Government in Peter Laslett, ed, John Locke: Two Treatises of Government (Cambridge: Cambridge University Press, 1988) 265 at 304).

Ford v Quebec (Attorney General), [1988] 2 SCR 712 at 764-65; Irwin Toy, supra note 70 ("his fate determined by his own powers of reason" at 970); Rocket v Royal College of Dental Surgeons of Ontario, [1990] 2 SCR 232 at 241; Keegstra, supra note 70 at 763; Rv Butler, [1992] 1 SCR 452 at 492. citing D Dyzenhaus "Obscenity and the Charter: Autonomy and Equality" (1991) 1 Criminal Reports (4th) 367 at 370 .

Irwin Toy, ibid at 968; Keegstra, ibid at 742, 805-806; Reference Re ss 193 and 195.1(1)(c) of the Criminal Code (Man), [1990] 1 SCR 1123 at 1180; Committee for the Commonwealth of Canada $v$ Canada, [1991] 1 SCR 139 at 172. 
When the state suppresses a person's ideas, or when the state suppresses that person's expression of those ideas, the state is insulting that person and affronting his dignity. There is a close link here with the concept of equality. When we suppress a person's ideas, we are in effect saying that although he may think his ideas to be as good as (or better than) the next person's, society feels otherwise. ${ }^{367}$

Hate speech legislation is aimed not at a person's ideas, but at the speech act that promotes hatred. $^{368}$ The effect nonetheless is to silence someone (or at least, to censure their expression), and to invoke Charter restraints when doing so is a significant innovation. It is an innovation that provides a fulcrum for the $D / L$ lever, by means of which Charter equality rights and values may again be invoked (as in Ismail) in the exercise of administrative discretion to justify use of state power. "Charter values" cases may provide further fulcra for the $D / L$ lever. As further Charter values are specified or elaborated by the courts, they may be invoked through $D / L$ balancing to support the exercise of discretion in favour of the use of state power.

The $D / L$ framework has transformative potential. The conjunction of progressive conceptions of Charter rights to support state action with the expansion of jurisdiction and deference to administrative tribunals considering Charter issues is likely to result in further novel uses of the Charter in pursuit of various agendas. Through our relatively short constitutional history we have preferred negative liberty as Isaiah Berlin described it, and no doubt for some of the same reasons. ${ }^{369}$ Charles Taylor has described these reasons as a "Maginot Line mentality" 370 that grew from fear of a totalitarian menace. This mentality may be changing, as a cohort of positive rights advances, with Charter cover, through a complex administrative Ardennes of commissions and tribunals. The creative and paradoxical application of an entrenched bill of rights in favour of state action, within private relations, and on the side of positive rights is grounded in fundamental values that will in time be more fully delineated. In Loyola, Justice Abella cited Aharon Barak in support of the principle that "the purpose of a constitutional right is the realization of its constitutional values." 371 Barak was writing in support of the constitutional value of human dignity, of which he wrote:

The dignity of a human being is his free will; the freedom to shape his life and fulfill himself.... At the core of a person's humanity stands the autonomy of her will, which means that the person herself — she, and no one else - determines her destiny. The state does not intervene in the affairs of the individual and in his

Frederick Schauer, Free Speech: A Philosophical Enquiry (Cambridge: Cambridge University Press, $1982)$ at 62.

368 Whatcott, supra note 16 at para 51

369 While Berlin's preference for negative liberty generally supports an orthodox constitutionalism, I do not intend to suggest that Berlin would have endorsed a simplistic application of his ideas to constitutional theory or a theory of justice. The implications of Berlin's philosophy for constitutional theory are not straightforward: see e.g. John Gray, "Introduction to the New Edition" in John Gray, Isaiah Berlin: An Interpretation of His Thought (Princeton: Oxford University Press, 2013) 1 at 11-16.

370 Charles Taylor, "What's Wrong With Negative Liberty?" in Alan Ryan, ed, The Idea of Freedom: Essays in Honour of Isaiah Berlin (Oxford: Oxford University Press, 1979) 175 at 179.

371 Loyola, supra note 9 at para 36, citing Aharon Barak, Human Dignity: The Constitutional Value and the Constitutional Right, translated by Daniel Kayros (Cambridge: Cambridge University Press, 2015) at 144. 
relations with others. Indeed, a person's humanity is her free will. This free will is denied if her choices are dictated by another person. ${ }^{372}$

The adaptability of Charter values within the $D / L$ framework, producing decisions reviewable on a reasonableness standard, has created opportunities for innovative constitutional claims within administrative law. The advocacy that has taken advantage of these opportunities has exposed tensions among competing conceptions of constitutionalism, some of which do not prioritize autonomy. It is possible that the aspect of human dignity that Barak describes, as well as the fundamental values of autonomy and freedom, will acquire new gravity as the limits of interpretation are tested.

The aim of this article has been mainly descriptive: to convince the reader that administrative decision-makers have begun to put the Charter to significantly innovative uses through the application of the $D / L$ framework. It is possible to prefer orthodox constitutionalism but remain consistently agnostic or ambivalent as to whether the discretionary deployment of Charter rights and values in new ways is a positive development. Opportunities for advancing worthy agendas may coexist with hazards for constitutionalism and the rule of law, and such hazards as there are might be mitigated as the $D / L$ jurisprudence develops. It would be at least premature to insist that deference to discretion that invokes Charter values to empower the state creates a "freedom-destroying cocktail." 373 There is much at stake, however, as tribunals assess claims grounded in equality rights that buttress state action, freedom of association rights that support a majoritarian collective bargaining structure, and Charter values that are vague and continuing to evolve. Whatever Charter values may be, there is only one set of them. As restraints they are benign, but they are not always being used as restraints. The Supreme Court has often warned that the aim of the Charter is not to impose "any one conception of the good life." ${ }^{374}$ The criticisms of Charter values-based analyses and the $D / L$ framework often involve a scepticism as to whether liberal pluralism can be robustly protected by universalist or rationalist means. ${ }^{375}$ The concern is not that proactively-enforced equality rights will knock

Barak, ibid at 144-45. This passage is not cited in an attempt to enlist Barak as a libertarian. Barak does not conceive of the constitutional value of human dignity purely as a protection from the state, or as admitting no conflict between rights. He conceives of human dignity as a value that may empower or constrain and which, for example through its "daughter rights" of freedom of expression and protection of reputation, may appear "on both sides" of the constitutional balance (ibid at 11, 122, 165). Barak does, however, describe "the autonomy of individual will" as standing "at the foundations of the constitutional value of human dignity" (ibid at 129).

373 Prado Navarette v California, 134 S Ct 1683 (2014) at 1697, Scalia J, dissenting.

374 See e.g. Morgentaler, supra note 69 at 166 (cited in $R$ v Salituro, [1991] 3 SCR 654 at 674; Quebec (Public Curator) v Syndicat national des employés de l'hôpital St-Ferdinand, [1996] 3 SCR 211 at 225); Zundel, supra note 171, Cory and Iacobucci JJ, dissenting; cf TW v LSBC SCC, supra note 21 at para 213, Rowe J, paras 328-34, Côté and Brown JJ, dissenting; TW v LSUC SCC, supra note 21 at para 75. See e.g. Gehl, supra note 24, especially at para 82; Trinity Western University v Nova Scotia Barristers Society, 2015 NSSC 25, aff'd supra note 211, especially at paras 271-75; TW $v$ LSBC SCC, supra note 21, especially at paras 181-93; Lauwers, "Liberal Pluralism," supra note 357. See also Peter D Lauwers, "Religion and the Ambiguities of Liberal Pluralism: A Canadian Perspective" (2007) 37 SCLR (2d) 1. The conflict between rationalist and pluralist liberalisms is a perennial issue in liberal theory. Jacob $\mathrm{T}$ Levy provides a nuanced and detailed treatment of the issue in his book Rationalism, Pluralism, and Freedom (Oxford: Oxford Scholarship Online, 2015). There he defends a pluralism he distinguishes from Berlin's. He describes pluralist liberalism as "skeptical of the central state and friendly toward local, customary, voluntary, or intermediate bodies, communities, and associations" (ibid at 2) and rationalist liberalism as "committed to intellectual progress, universalism, and equality before a unified law, opposed to arbitrary and irrational distinctions and inequalities, and determined to disrupt local tyrannies in religious and ethnic groups, closed associations, families, plantations, the feudal countryside, and so on" (ibid). 
the sharp edges off discourse, render the public space beige, and enforce an excess of moderation, but that they will exclude religious groups and other minority voluntary associations from public life, homogenize the membership of publicly-regulated professions, and muffle minority opinion.

While the danger of imposing values may be magnified at tribunals that make decisions outside the rule of law, unbound by precedent, and reviewable only on a reasonableness standard, it may be countered that the strength of tribunals is their discretion and proximity to the people involved in individual cases. It is possible that the decisions of tribunals, in their particularity and through their exercise of discretion that does not bind other decisionmakers, may best preserve Berlin's agonistic liberalism, which avoids absolutes and perfectibilism but maintains "an uneasy equilibrium, which is constantly threatened and in constant need of repair," 376 while preserving the greatest possible opportunity, through constant compromise, for the pursuit of genuinely individual ends. Berlin was sceptical of positive rights, however, not because he viewed limited government as an ideological end in itself, but because he believed a restrained state was more likely to tolerate diversity. Positive enforcement of Charter equality through administrative rulings may compromise that diversity. Whether any of these concerns are justified, however, is too large a question to be answered convincingly without the benefit of much greater hindsight. 
[this page is intentionally blank] 